Portland State University

PDXScholar

Environmental Science and Management

Professional Master's Project Reports

Spring 2018

\title{
Effects of Beaver Dams on Urban Stream Hydraulic Response During Storm Events
}

\author{
Erin Poor \\ Portland State University
}

Follow this and additional works at: https://pdxscholar.library.pdx.edu/mem_gradprojects

Part of the Environmental Studies Commons, and the Water Resource Management Commons Let us know how access to this document benefits you.

\section{Recommended Citation}

Poor, Erin, "Effects of Beaver Dams on Urban Stream Hydraulic Response During Storm Events" (2018). Environmental Science and Management Professional Master's Project Reports. 28.

https://pdxscholar.library.pdx.edu/mem_gradprojects/28

https://doi.org/10.15760/mem.8

This Project is brought to you for free and open access. It has been accepted for inclusion in Environmental Science and Management Professional Master's Project Reports by an authorized administrator of PDXScholar. Please contact us if we can make this document more accessible: pdxscholar@pdx.edu. 


\title{
Effects of Beaver Dams on Urban Stream Hydraulic Response During Storm Events
}

\author{
by \\ Erin Poor
}

\author{
A report submitted in partial fulfillment of the \\ requirements for the degree of \\ Master of Environmental Management \\ Project Committee: \\ Jennifer Morse (PSU) \\ Stewart Rounds (USGS) \\ Krista Jones (USGS)
}

The Department of Environmental Science and Management

Portland State University

April, 2018 


\section{ACKNOWLEDGEMENTS}

I would like to thank my friends and family for their love and support throughout this journey. My kids, Cyrus and Bella, inspired me to become a student and have encouraged me and shown me compassion throughout my education. My parents, David and Kathy, taught me to follow my happiness and showed me the importance of a good education. My grandma, Joyce, has provided me with love and support every step of the way.

Thank you to my co-workers who inspire and impress me with their knowledge, kindness and passion for science. I have learned so much from each of them and look forward to exploring what lies around the next river bend.

Lastly, I would like to thank my committee, Jen Morse, Stewart Rounds and Krista Jones. I could not have asked for a better team to support me through this process. They have provided me with guidance when needed and allowed me the freedom to explore my interests. 


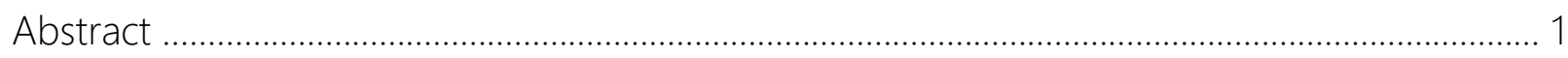

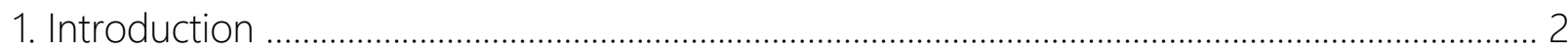

1.1 Background and Purpose ............................................................................................... 5

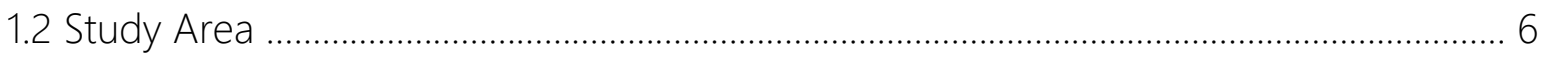

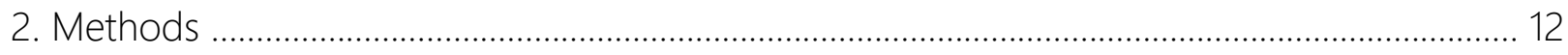

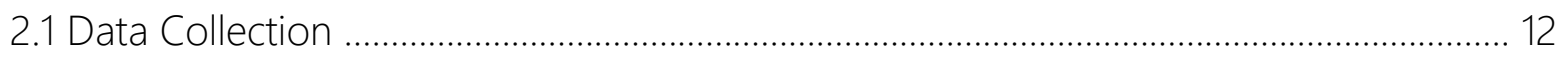

2.2 Rate-of-Change Frequency Analysis .............................................................................. 16

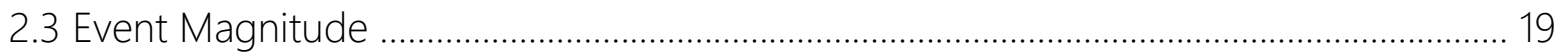

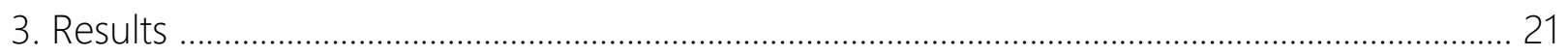

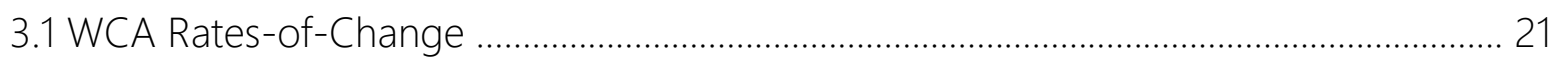

3.2 Normalized Peak Magnitude Comparison .......................................................................... 25

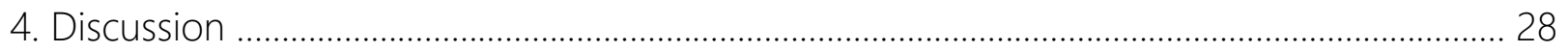

4.1 Hydrologic Response During Storm Events .................................................................... 28

4.2 Limitation to Study Design ............................................................................................. 31

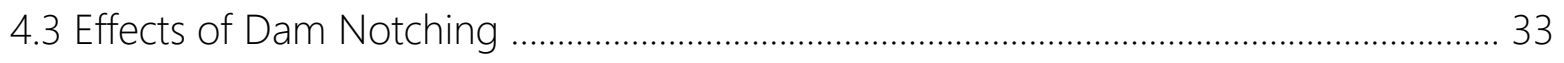

4.4 Implications for Management ………………………………………………........ 34

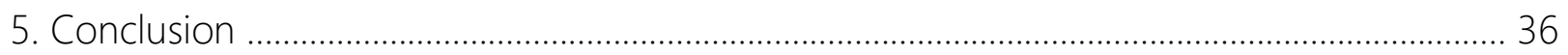

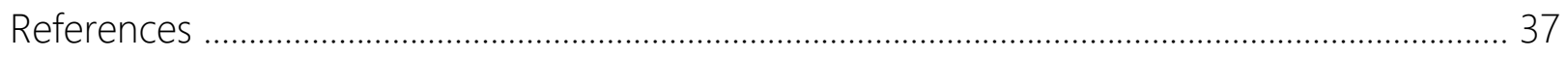

Appendix A - Community Partner ....................................................................................... 40 
Figure 1: Hypothetical urban hydrograph 3

Figure 2: Map of the Tualatin Basin 7

Figure 3: Average monthly rainfall 8

Figure 4: Map of Fanno Creek at Greenway Park 10

Figure 5: Map of Stoller Creek near Springville 11

Figure 6: Channel cross section at upstream Fanno Creek 16

Figure 7: Autocorrelation plots 19

Figure 8: Example of results from the event initiation identification 21

Figure 9: Findings from the frequency analysis at Fanno Creek 23

Figure 10: Findings from the frequency analysis at Stoller Creek 24

Figure 11: Findings from the frequency analysis comparing Stoller and Fanno Creeks........... 25

Figure 12: Plots comparing event magnitude at Fanno Creek 26

Figure 13: Map showing bathymetric survey at Fanno Creek 27

Figure 14: Photographs during a storm event at Fanno Creek 27

Figure 15: Plot comparing event magnitude at Stoller Creek 28

Figure 16: Graphs showing changes to stage after a dam notching event 30

Figure 17: Diagram of contributing area for the study sites 33

Figure 18: Decisions tree 35 


\section{List of Tables}

Table 1: Comparison of site characteristics .................................................................................. 9

Table 2: Rules defining the beginning of a storm event ..................................................... 20 


\section{ABSTRACT}

Urbanization of landscapes alters watershed hydrology, leading to changes in the natural flow regime of local streams. Runoff from impervious surfaces and routing of stormwater can cause a rapid increase in the volume and velocity of streamflow. This is observed in the hydrograph as a steep rising limb, followed by a high peak, and a rapid falling limb. This rapidly varying streamflow, often referred to as flashiness, can increase erosive forces on the channel bed and banks, leading to channel incision and bank erosion. In areas where the hydrologic regime is less impacted by humans, beaver dams and ponds attenuate storm flow, resulting in a hydrograph that responds more gradually to storms. Currently, however, no studies have been published that examine how beaver dams affect streamflow in urbanized systems. This study seeks to determine whether the presence of beaver dams and ponds in urban stream reaches reduces stream flashiness and decreases the magnitude of storm events. In the Tualatin River Basin, in northwestern Oregon, surface water stage was collected upstream and downstream of two beaver affected stream reaches in the urban portion of the watershed. Continuous stage measurements were combined with channel cross-sectional measurements to derive the wetted cross-sectional area, a timeseries variable that was used as a surrogate for discharge to assess the effects of beaver dams on hydraulic change during storm events. Results showed a moderate decrease in the magnitude of most storm event peaks downstream of beaver-affected reaches, indicating a dampening of streamflow during periods of heavy rainfall. The effects of the beaver dams and ponds on

\section{Page | 1}


hydraulic variability were quantified using a frequency analysis of the rate-of-change in the wetted cross-sectional area, which tended to reinforce the observed reduction in streamflow variability during storms. The degree of attenuation varied between the two sites, suggesting that other factors influence the efficacy of beaver dams and ponds at dampening streamflow variability during storm events.

\section{INTRODUCTION}

Land-use changes that increase the amount of impervious surface across a landscape can alter the natural flow regime of local streams. The development of landscapes increases the area of roads, rooftops, and other hard surfaces, which prevents stormwater from infiltrating into the ground. The result is more runoff and less storage within the landscape. Stormwater in a typical urban landscape is routed to streams more quickly and at a higher volume than would occur in a less impacted landscape, decreasing the lag time between a precipitation event and an increase in streamflow (Arnold and Gibbons, 1996). As an area becomes

urbanized, streams are often re-routed and channelized to fit the built environment. Similarly, as wetlands are filled and developed, the capacity of the landscape to store water decreases, and the magnitude of high flow events increases (Poff, et al., 1997). These land-use changes cause the flows and water levels of urban streams to rise and fall more rapidly than their lessaltered counterparts (Figure 1). This rapid variation in streamflow is commonly referred to as 
stream flashiness. Flashiness is observed in the hydrograph as a steep rising limb, a higher peak and a rapid falling limb (Baker and Richards, 2004). The steep slope of a flashy hydrograph typically has higher rates-of-change than a less flashy hydrograph.

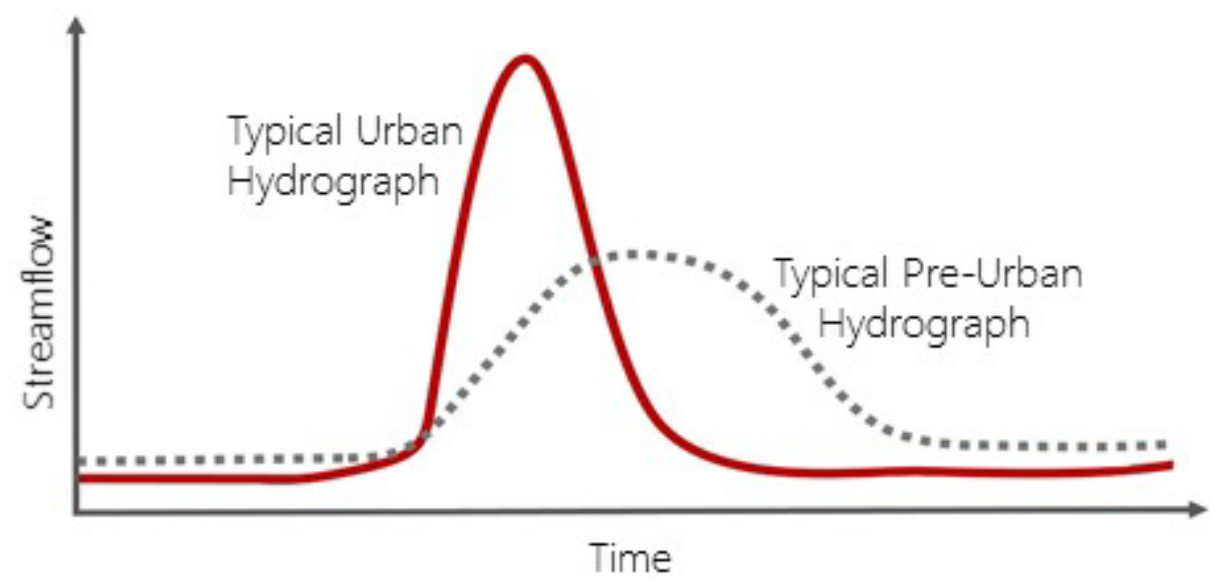

Figure 1. Hypothetical hydrograph showing the response of a pre-urban stream to a storm event. The response is more gradual with smaller rates-of-change than its urbanized counterpart that responds rapidly with intense rates-of-change.

Altering the natural flow regime can have negative impacts on the stream channel and surrounding riparian area. Flashy, channelized streams have high stream power during storms that can scour stream banks and incise the stream channel (Booth, 1990). That incision tends to disconnect the stream from its floodplain at all but the highest flows, and further promotes a flashy response by confining storm flows to the deeper, incised channel. The simplification of the stream channel and changes to the natural hydrologic regime decreases habitat diversity and results in a decline in native species diversity (Poff, et al., 1997). 
Beaver dam building activity could potentially alleviate some of the negative impacts to streams caused by urbanization. Dams impede surface water flow and push water onto the floodplain, creating ponds that provide suitable habitat for beaver and allow them to safely traverse the streamscape. Surface water flow paths diversify, and floodplain connectivity is further promoted, as beaver dig canals to transport large wood. Studies in forested and rural streams that are less altered by human activity show that beaver dams benefit stream health and provide ecological uplift (Wright, et al., 2002; Westbrook, et al., 2006; Giriat, et al., 2015). For example, dams increase the volume of water stored in the stream network by dispersing water laterally across the landscape (Puttock, et al., 2016). Beaver ponds can buffer stormflow events, which increases the lag time between precipitation peak and downstream peak discharge. Water stored in beaver ponds during storms is gradually released, lengthening the duration of event flow and decreasing the magnitude of peak events (Nyssen, et al., 2011; Puttock, et al., 2016). Currently no studies have been published that examine how beaver dams affect streamflow in urban systems that have an altered hydrologic response. Because urban streams typically respond differently to storm events than streams that are less impacted by humans, it is unclear whether these beaver-related hydraulic benefits exist in an urban setting.

\section{Page | 4}




\subsection{Background and purpose}

Clean Water Services (CWS) is the primary wastewater and stormwater management utility in the urban portions of the Tualatin River Basin (TRB; Figure 2). In 2016, the Oregon Department of Environmental Quality asked CWS to incorporate a hydromodification plan into their watershed-based stormwater permit. The purpose of the hydromodification plan would be to better manage increases in the amount and timing of water entering streams during storm events. In their planning efforts, CWS identified beaver as a potential in-stream hydromodification tool, knowing that beaver activity tends to reduce the hydraulic effects of storm events in less-impacted streams and that beaver are native to and increasing in abundance in the TRB. CWS partnered with the U.S. Geological Survey to quantify the effects of beaver on the geomorphology, hydrology, ecology and water quality of urban streams in the TRB.

This paper quantifies the effects of beaver on hydraulic changes during storm events by addressing several key questions: (1) do beaver dams and ponds buffer the rapid rates-ofchange in stream discharge (or its proxy, wetted cross-sectional area) that are common on the rising and falling limbs of an urban stream hydrograph?; (2) do the magnitudes of peak streamflows during storms decrease downstream of a beaver reach?; and (3) do beaver ponds store water during storms and release it more gradually over a longer period of time? This research will inform local resource management decisions by helping to quantify the 
benefits and limitations of beaver activity on mitigating streamflow changes associated with urbanization on streams in the TRB.

\subsection{Study area}

The TRB encompasses 712 square miles $\left(\mathrm{mi}^{2}\right)$ in northwestern Oregon (Figure 2). The regional climate is characterized by a Mediterranean climate, with a cool, wet period that extends from approximately October through May and a warm, dry period from June through September. Eighty-five percent of the annual precipitation occurred from October to March during the data collection period (Figure 3). The headwaters of the Tualatin River and three of its main tributaries (Dairy, Scoggins and Gales Creeks) are located in the Oregon Coast Range, an area that is characterized by steep forested terrain. The average slope in this reach of the Tualatin River is 14 meters per kilometer (Bonn, 2016). The terrain flattens in the valley where the majority of the urbanization has occurred. The lower reach of the Tualatin River has an average slope of less than 2 meters per kilometer. 


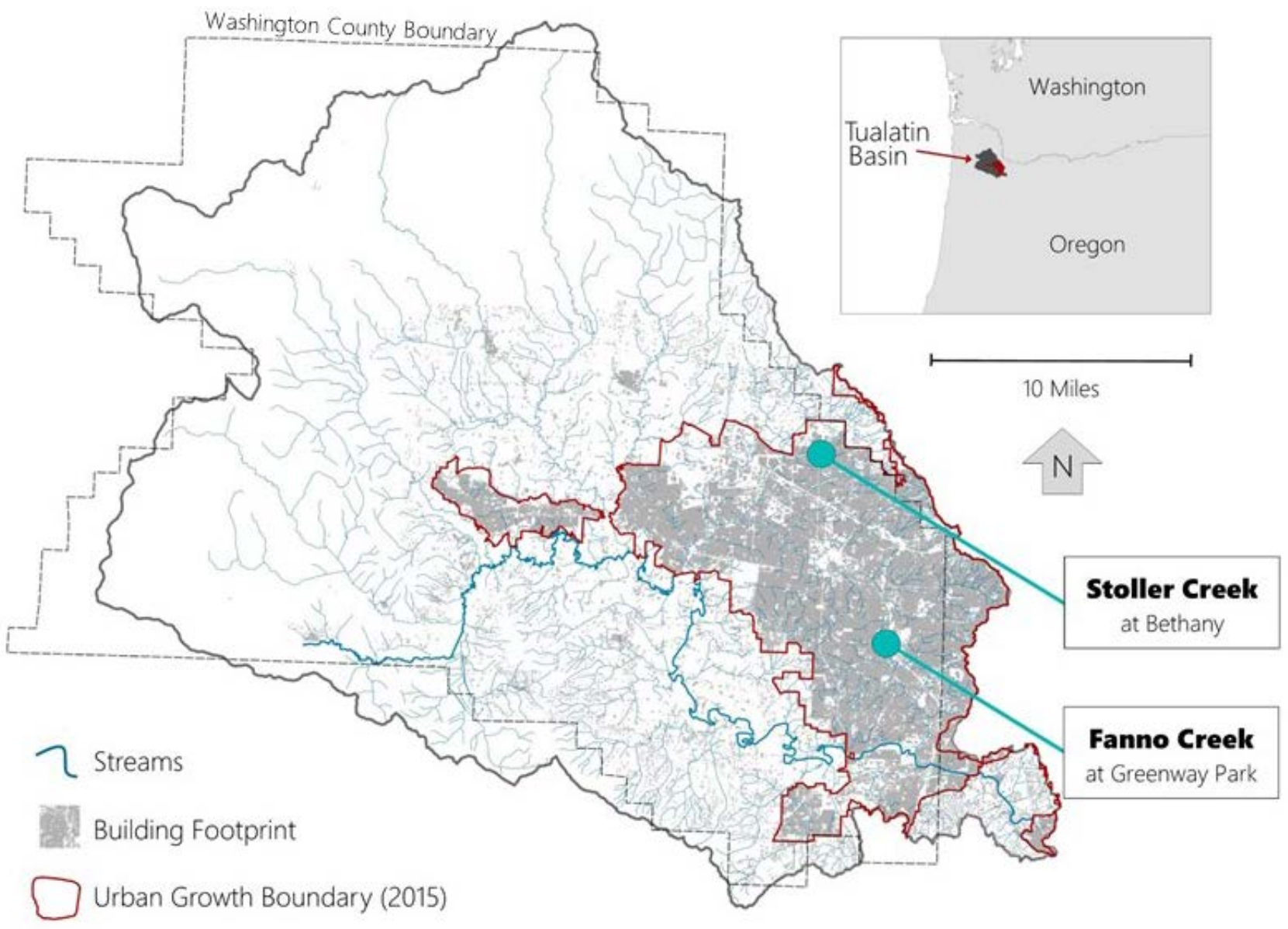

Figure 2. The Tualatin basin is located on the west side of the Portland metropolitan area. The eastern portion of the basin falls within the urban growth boundary, creating a dense suburban landscape. Both study sites, Fanno and Stoller Creeks, are located within the urban growth boundary. 


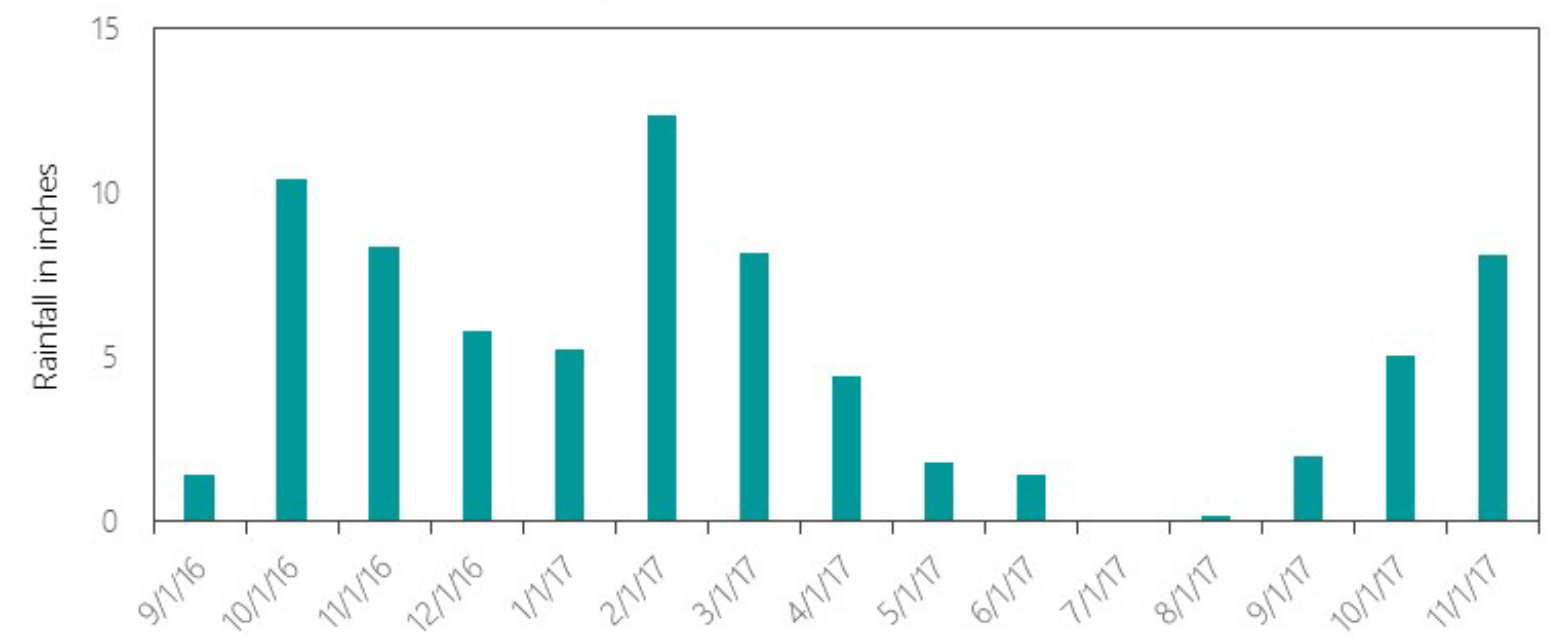

Figure 3. Monthly rainfall in the urban portion of the Tualatin Basin, 2016-2017. Eighty-five percent of the rainfall occurred during the months of October to March. Data was averaged from five rain gages located at different sites in the Tualatin basin. Data was collected by Clean Water Services.

The TRB region is rapidly urbanizing, which has important effects on basin hydrology. The majority of the TRB falls within Washington County, one of the fastest growing counties in Oregon (Rynerson, 2017). In 2016, Washington County accounted for $20 \%$ of the population growth in Oregon. The spatial extent of that growth is constrained by the urban growth boundary (UGB), for the Portland, Oregon metropolitan area; the UGB is one result of a comprehensive land-use planning law passed in Oregon in 1973 to minimize encroachment of development onto productive farm and forest lands. The UGB, coupled with continued population growth, has created a densely populated urban and suburban environment. The majority of the population resides in a concentrated portion of the watershed (Figure 2). Development within the UGB from 1976 to 2000 increased the amount of runoff (Chang, 
2007), leading to streams with flows and water levels that rise and fall at quicker rates (Smith and Ory, 2005).

Two beaver-affected reaches were the focus of this study: Fanno Creek at Greenway Park (Figure 4), and Stoller Creek at Bethany (Figure 5). These sites are both located within the urban growth boundary but have several contrasting characteristics (Table 1), including contributing area, percent impervious surface, intensity of development and channel slope. Fanno Creek is one of the major tributaries to the Tualatin River. The $10 \mathrm{mi}^{2}$ contributing area upstream of the Fanno Creek study reach consists of a well-established, low gradient urban landscape that saw a surge in development beginning in the 1970s. The 950-meter stream reach decreases in elevation by just 1 meter from the upstream sampling location to the downstream location (slope $=1.05$ meters per kilometer). A family of beavers settled into Fanno Creek at Greenway Park in 2012 and built multiple dams that created a large pond (South Pond, Figure 4) and flooded local trails. Prior to the recent colonization by the beaver, thousands of native plants were planted at the park, and have subsequently provided adequate foraging and dam-building material. The second site, Stoller Creek, is a smaller stream with a $0.5 \mathrm{mi}^{2}$ contributing area that was initially developed in the early $1990 \mathrm{~s}$. The 880-meter stream reach decreases by 9 meters in elevation from the upstream sampling location to the downstream location (slope=10.23 meters per kilometer). Beaver took up

\section{Page | 9}


residence at this site in 2015, and built multiple valley spanning dams, which turned the small stream channel into a series of ponds.

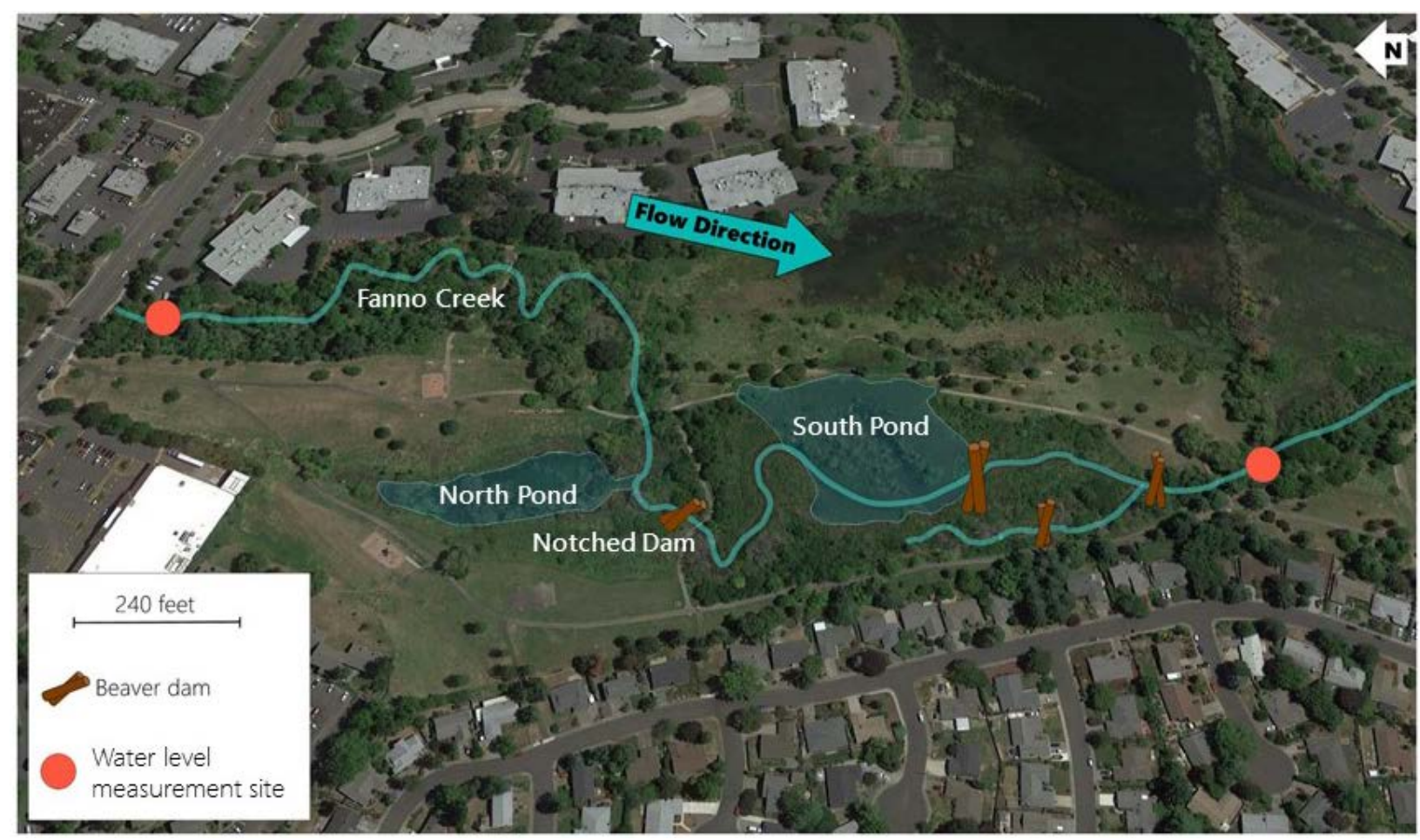

Figure 4. Map of Fanno Creek at Greenway Park in Beaverton, Oregon. 


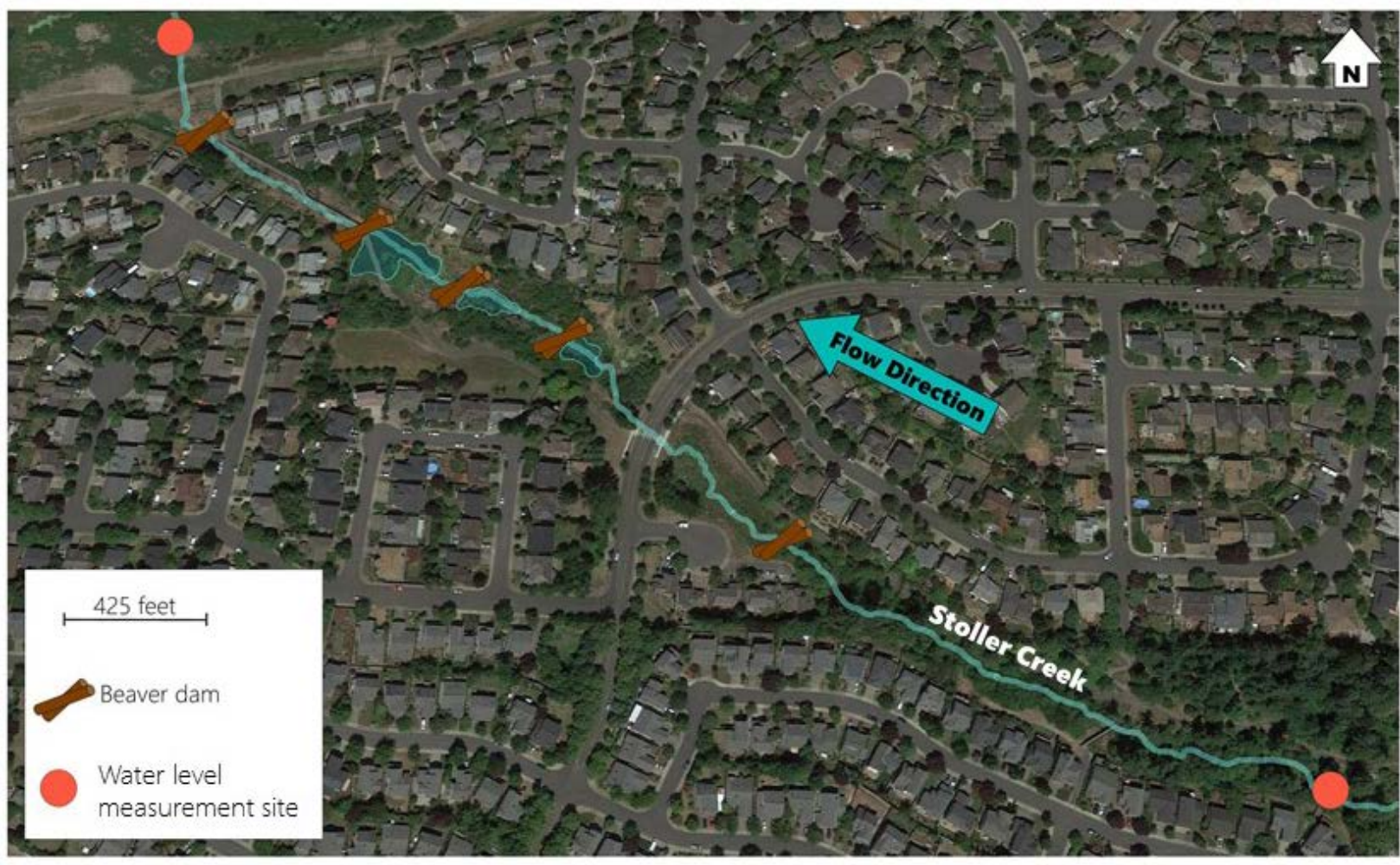

Figure 5. Map of Stoller Creek at Bethany, near Springville Creek in Portland, Oregon.

Table 1. Comparison of site characteristic between the Fanno Creek and Stoller Creek sites.

\begin{tabular}{|l|l|l|l|}
\hline Site Parameter & $\begin{array}{l}\text { Fanno } \\
\text { Creek }\end{array}$ & $\begin{array}{l}\text { Stoller } \\
\text { Creek }\end{array}$ & Data Source/Calculation Method \\
\hline Contributing area (square miles) & 10.3 & 0.52 & USGS Stream Stats \\
\hline Length of stream reach (meters) & 950 & 880 & Calculated using Google Earth \\
\hline Sinuosity & 1.46 & 1.29 & Sinuosity= (length of stream reach)/(length of straight line distance) \\
\hline Stream Reach Slope (meters per kilometer) & 1.5 & 10.23 & Slope=Rise/Run \\
\hline Mean contributing area slope (degrees) & 2.76 & 1.56 & USGS Stream Stats \\
\hline Impermeable surface (square miles) & 4.3 & 0.1 & USGS Stream Stats \\
\hline $\begin{array}{l}\text { Percent of contributing area with impermeable } \\
\text { surface (\%) }\end{array}$ & $42 \%$ & $18 \%$ & Calculation based on USGS Stream Stats data \\
\hline $\begin{array}{l}\text { Percent of developed area, high intensity } \\
\text { development (\%) }\end{array}$ & $100 \%$ & $11 \%$ & USGS Stream Stats \\
\hline $\begin{array}{l}\text { Percent of developed area, medium intensity } \\
\text { development }(\%)\end{array}$ & $0 \%$ & $24 \%$ & USGS Stream Stats \\
\hline $\begin{array}{l}\text { Percent of developed area, low intensity } \\
\text { development }(\%)\end{array}$ & $0 \%$ & $56 \%$ & USGS Stream Stats \\
\hline Estimated 2 Year Peak Flood $\left(\mathrm{ft}^{3} / \mathrm{s}\right)$ & 278 & 13.4 & USGS Stream Stats \\
\hline Estimated 5 Year Peak Flood $\left(\mathrm{ft}^{3} / \mathrm{s}\right)$ & 421 & 20.1 & USGS Stream Stats \\
\hline Estimated 10 Year Peak Flood $\left(\mathrm{ft}^{3} / \mathrm{s}\right)$ & 521 & 24.8 & USGS Stream Stats \\
\hline Estimated 25 Year Peak Flood $\left(\mathrm{ft}^{3} / \mathrm{s}\right)$ & 650 & 30.9 & USGS Stream Stats \\
\hline Estimated 50 Year Peak Flood $\left(\mathrm{ft}^{3} / \mathrm{s}\right)$ & 747 & 35.5 & USGS Stream Stats \\
\hline
\end{tabular}

\section{Page | 11}


Different development histories also contribute to hydrologic contrasts in the two study catchments: they were developed decades apart and under different rules regulating development. The implementation a Surface Water Management (SWM) Program in the early 1990s regulated activities that could negatively affect watershed health. The program required all new development occurring in Washington County after 1991 to treat stormwater using techniques such as swales. At the time, the purpose of these stormwater facilities was to remove pollutants (often through infiltration into the soils). However, the facilities likely provided ancillary benefits by decreasing the volume or rate of runoff entering streams during storm events. Additionally, during the early 1990s the county implemented a riparian buffer rule that prohibited most development from occurring within 7.5 meters of the stream bank (Ozawa and Yeakley, 2007). Both of these regulatory changes likely influenced development along Stoller Creek, but probably had little impact on Fanno Creek which was largely developed prior to the implementation of such rules.

\section{METHODS}

\subsection{Data Collection}

Data were collected upstream and downstream of the beaver-affected reaches to quantify the effects of beaver dams and ponds on stream hydraulics. Continuous stage data were collected using an unvented Solinst pressure transducer (model 3001 Levelogger Edge LT M5 
F15) in areas with free-flowing water. The stage data were corrected for atmospheric pressure variations using Solinst barometric pressure sensors (model 3001 Barologger Edge M1.5 F5) near the two study sites. Recording intervals were set to a frequency of 15 minutes to capture rapid changes in stage. Using surveyed elevations for reference marks at each water-level measuring station, the stage data were later converted to water-level elevations, relative to the North American Vertical Datum of 1988 (NAVD88). This approach was successful at all sampling locations except the upstream location at Stoller Creek because it lacked proper satellite coverage to support the reference-mark survey. An arbitrary datum was chosen for the upstream Stoller Creek sampling location. Channel cross sections (stream bottom and bank elevation as a function of location across the channel) were surveyed at the locations of each pressure transducer using a Real Time Kinematics Global Positioning System at all sampling locations, except at the upstream Stoller Creek location where an engineering level was used.

Channel cross-sectional information was combined with the continuous stage measurements to derive a new time-series called wetted cross-sectional area (WCA). WCA represents the area of the channel cross section that is filled with water at each stage measurement. WCA was used as a surrogate for stream discharge to examine changes in stream flashiness and event magnitude between the upstream and downstream sampling locations. Ideally, streamflow data derived from stage data would be used to analyze stream flashiness, but 
insufficient measurements of streamflow were available to develop defensible stagedischarge relations for these sites.

Like streamflow measurements, WCA is computed using water level and channel width, but unlike streamflow, velocity is not included in WCA calculations. Velocity can affect the amount of water passing through a cross section; for that reason, 13 velocity measurements recorded at the upstream and downstream sampling locations on Fanno Creek were compared. Velocity measurements were recorded when measuring stream discharge for another portion of the study. Unfortunately, these measurements were not made at the Stoller locations, but velocity comparisons are not normally done when using WCA, so it was assumed that the WCA approach was still appropriate. A paired t-test assuming equal variance was applied using R statistical software (R Core Team, 2017) to determine if velocity measurements collected at the upstream Fanno sampling location were significantly different from the downstream sampling location. Prior to the analysis, the velocity datasets were tested for equal variance and normality and were found to meet both assumptions for a paired t-test.

WCA has been shown to be more useful than stage data when analyzing hydraulic changes when a stage-discharge relation was not well-established (Brown et al., 2009; Richards, et al., 2010). Booth and Konrad (2017) found that a common metric of streamflow variability, the

\section{Page | 14}


Richard-Baker Index for flashiness, was not accurately calculated using stage data, but could be computed using water depth. Water depth is incorporated in the calculation of WCA, but WCA goes a step further by including the entire area of flow. WCA can be used to calculate a range of hydrologic metrics but it does have limitations, particularly because it cannot be used to calculate the volume of water moving through a site. Volume estimates would have been useful in this study as they would have allowed water stored within the beaver reach to be quantified.

Stage data were recorded at Fanno Creek from June 2016 to November 2017 and at Stoller Creek from February 2017 to December 2017. Data collected during summer were excluded from WCA rate-of-change analysis because minimal rainfall occurred during this period; therefore, the streams were typically at baseflow conditions during summer. Beaver built a dam downstream of the downstream level logger at Stoller Creek during the summer of 2017, causing water to pool at the downstream sampling location. Data from that period were excluded from the analysis because the stage data and the derived WCA data were no longer representative of the streamflow at that site. Additionally, two storm events were excluded from the Fanno Creek analysis (11/24/2016 and 2/5/2017-2/6/2017) because the events were large enough for the stream to overflow the right bank and inundate the floodplain at the cross section where the upstream level logger was located. The stream overflowed the right bank when the stage exceeded an elevation of 53.66 meters (figure 6), 
causing a sharp increase in WCA that was believed to be a poor representation of the change in flow at the site.

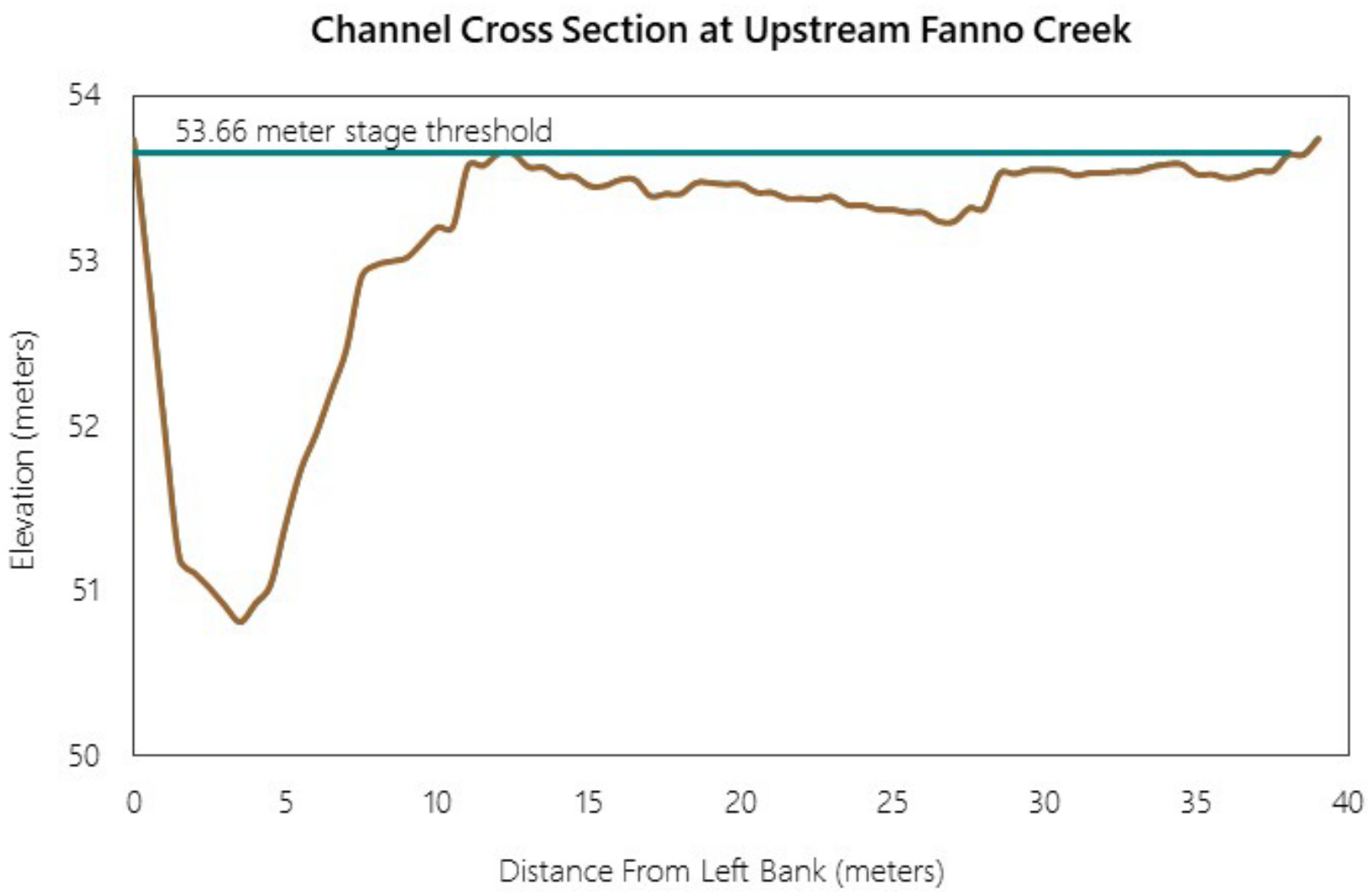

Figure 6. When the stage at upstream Fanno Creek exceeded an elevation of 53.66 meters the stream exited the right bank. A sharp increase was observed in the WCA during the two storms where this threshold was exceeded. These storm events were removed because it was presumed to be a poor representation of the change in flow at the site.

\subsection{Rate-of-Change Frequency Analysis}

Metrics were calculated to assess the rate-of-change in WCA at the upstream and downstream sampling locations. The WCA time step was increased to minimize autocorrelation so that the results could be tested for significant differences between the 
upstream and downstream sampling locations. The time step was increased from 30 minutes to 360 minutes for the Fanno Creek dataset and from 15 minutes to 90 minutes for the Stoller Creek dataset. The average time for a storm to go from baseflow to storm peak at Fanno Creek was 580 minutes, so the adjusted interval still captured the timeframe of a typical storm event. The same was true for the adjusted time step at Stoller Creek where the average time from baseflow to storm peak was 210 minutes. The presence of autocorrelation was evaluated using R statistical software (R Core Team, 2017). The results for Fanno Creek (Figure 7a) show that no significant autocorrelation is present at the upstream location once the sampling interval was adjusted. Two time lags show some significant autocorrelation at the downstream location; however, the correlation is present in data sampled multiple days apart, so that type of autocorrelation is not of concern for this analysis. The results of autocorrelation plots for Stoller Creek showed no significant correlations in the adjusted datasets (Figure $7 b$ ).

A frequency analysis was used to evaluate stream flashiness based on rates-of-change in the WCA time series. The frequency analysis provided a count of the number of times that the WCA rate-of-change exceeded specific thresholds, with the hypothesis that higher rates-ofchange are indicative of more variability, and therefore flashier streamflow conditions. Median rates-of-change were calculated for the rising and falling limbs of the WCA hydrograph for each storm at the upstream and downstream sampling locations, and that

\section{Page | 17}


median was multiplied by 3, 5, 7 and 9 to create four thresholds representing different magnitudes of change (the method for calculating thresholds was also used by McMahon et al. (2003), Richards et al. (2010), Phillips and Scatena (2010). Positive rates-of-change were classified as part of the rising limb of a storm hydrograph, while negative rates-of-change were classified as part of the falling limb. Frequency counts and medians were calculated for the rising and the falling limbs separately. The results at the upstream sampling location were compared to those from the downstream location to determine whether counts decreased downstream, which would indicate a reduction in stream flashiness. An additional frequency analysis was conducted using data from comparable time periods at the upstream Stoller and upstream Fanno Creek sites to determine if one stream was significantly flashier than the other.

A chi-square test for independence (Microsoft Excel, 2016) was used to determine whether the frequency counts between the upstream and downstream sampling locations were statistically similar. The frequency analysis resulted in a categorical variable because it counted each time a threshold was exceeded. A chi-square test is used to test the independence of categorical variables, making it a good fit for this dataset. Additionally, the Wilcoxon rank-sum test was used to test whether the frequency of high rates-of-change (rates-of-change that exceeded three-times the median) were statistically different between upstream and downstream sampling locations. The Wilcoxon rank-sum was computed using 
R statistical software (R Core Team, 2017) and was used because the datasets were not normally distributed and it because it allowed for a different number of observations in the two datasets.

(7a)

Fanno Creek Autocorrelation Plots

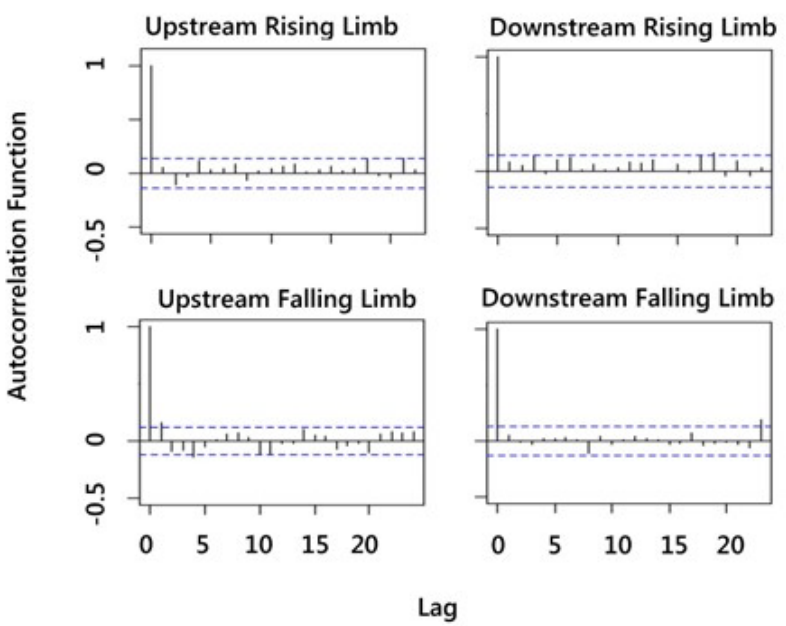

(7b)

Stoller Creek Autocorrelation Plots

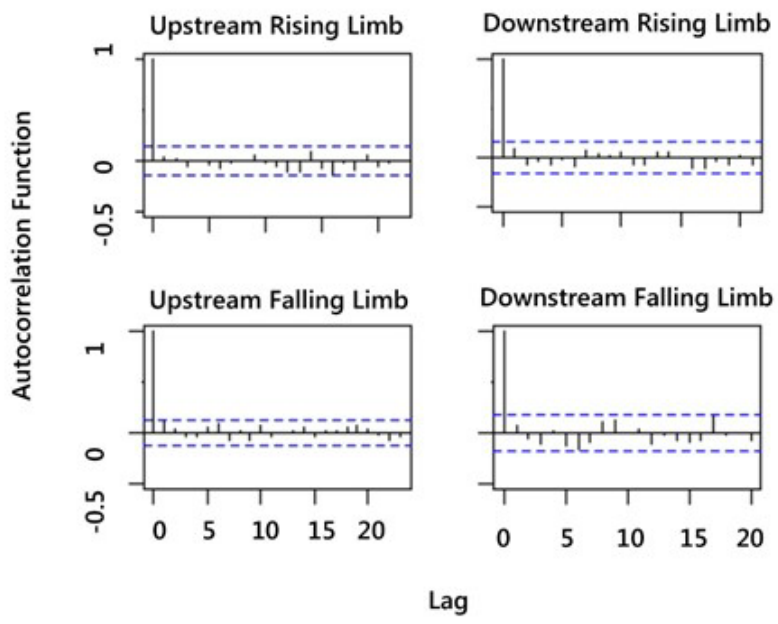

Figure 7. Autocorrelation plots show whether data points in a timeseries are correlated to each other. The vertical lines show the degree of autocorrelation at each time lag. If autocorrelation is statistically significant the lines will cross the blue dashed line. The results for Fanno Creek (7a) show that there is no significant autocorrelation at the upstream site. There are two time lags where significant autocorrelation is present at the downstream site. The correlation is present in data sampled multiple days apart, so it's not of concern. The results for Stoller Creek (7b) show there is no significant autocorrelation in all of the datasets.

\subsection{Event Magnitude}

A storm-event separation analysis was conducted to assess whether the presence of beaver dams and ponds might decrease the peak magnitude of streamflow or water level during storm events at sites immediately downstream, thus buffering the effects of those storms on 
the stream hydrograph. A storm event was assumed to begin when the positive WCA rateof-change exceeded a predetermined threshold for a set amount of time (Table 2).

Comparable event starts for the upstream and downstream site locations were identified and used for the analysis (see Figure 8 for example results from Fanno Creek for March 2016). The magnitude of peak events was calculated by subtracting the WCA at the start of the event from the peak WCA, thus defining the peak magnitude as the maximum change in WCA for each event. The peak magnitude was then divided by the median WCA at each sampling location to account for differences in baseflow so that the normalized peak magnitudes (NPM) were more comparable among sampling locations (Richards, et al., 2010).

Table 2. Rules used to define the beginning of a storm event. Averages and percentiles were calculated for each site using rate-of-change data for the period of analysis. [ROC = rate-of-change in wetted cross-sectional area]

\begin{tabular}{|l|l|}
\hline & Start of Storm Event \\
\hline Fanno Creek & ROC $>$ average PROC for at least 1.5 hours \\
\hline Stoller Creek & $\begin{array}{l}\text { ROC } \geq 85 \text { th percentile } \\
\text { or } \\
\text { ROC }>\text { average PROC or }<\text { double the average NROC, } \\
\text { for at least an hour }\end{array}$ \\
\hline
\end{tabular}

$P R O C=$ positive rate-of-change (rate of change in rising continuous wetted area) $N R O C=$ negative rate-of-change (rate of change in falling continuous wetted area) 


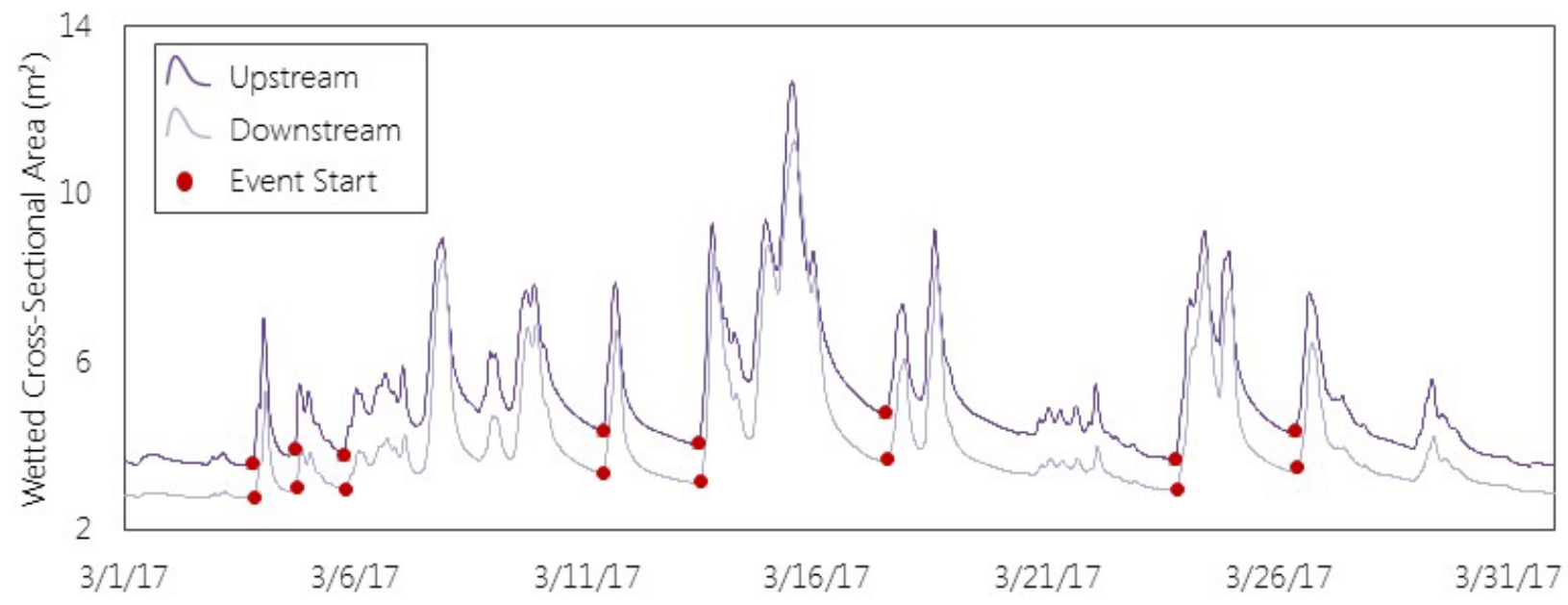

Figure 8. Example of results from the event initiation identification at Fanno Creek for the month of March 2016. Red circles signal the start of storm events using the criteria listed in table 2.

A Wilcoxon signed-rank test was conducted using R statistical software (R Core Team 2017) to assess whether the NPM were statistically different downstream when compared to upstream. The Wilcoxon signed-rank test is a non-parametric alternative to a paired t-test. It is useful when a dataset does not meet the assumption of normality, a requirement for a t-test, as was the case with the NPM datasets at both Fanno and Stoller Creeks.

\section{RESULTS}

\subsection{WCA Rates of Change}

At the Fanno Creek site, no significant difference was found between velocity measurements at the upstream and downstream locations $(p=0.09474)$, suggesting that the WCA are 
comparable between the sampling locations. At Fanno Creek, the occurrences of rapidly changing WCA on the rising limb were significantly different between the upstream and downstream sampling location (chi-square test for independence, $p=0.046$ ). Results in figure 9a show that rapidly changing WCA that were three, five, and seven times the median rateof-change, occurred more frequently at the downstream sampling location. At the highest threshold, nine times the median, there was a substantial decrease downstream. Results from the Wilcoxon rank sum test show that there is a significant $(p=0.02)$ difference in the WCA rates-of-change that exceeded three-times the median. On the falling limb at Fanno Creek, figure 9 shows a decrease downstream in the occurrence of rates-of-change that exceeded the nine times the median threshold (Figure 9b), but, when testing all thresholds no significant differences were found in the frequency of occurrence (chi-square test for independence, $p=0.634)$. Additionally, the high rates of change were not significantly different when comparing the upstream to downstream (Wilcoxon rank sum, $p=0.27$ ). 

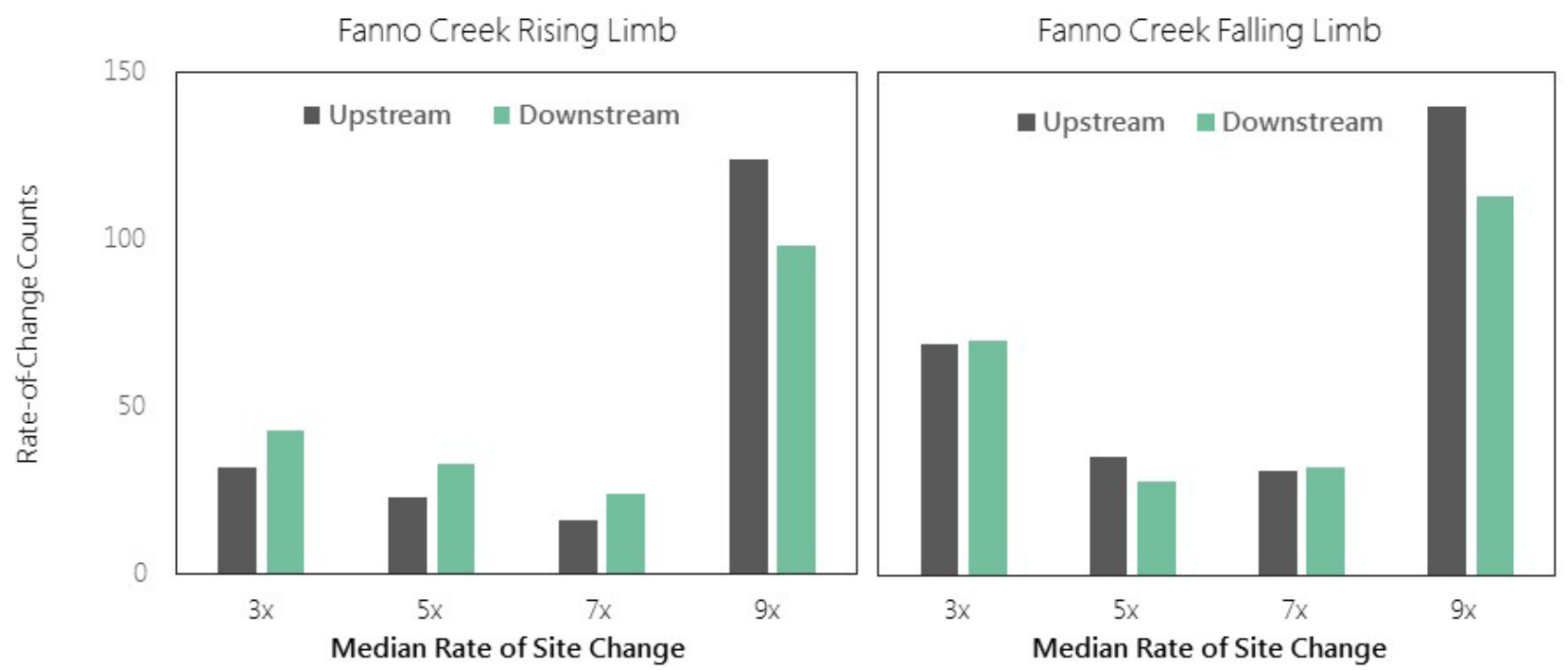

Figure 9. Findings from the frequency analysis of WCA rates-of-change at Fanno Creek show that the rising limbs at the upstream and downstream sites respond differently to storm events (chi-square test for independence, $p=0.046$ ). Conversely, there is no significant (chisquare test for independence, $\mathrm{p}=0.634$ ) difference in the occurrence of high rates-of-change in the falling limb as the stormwater recedes.

Results from the Stoller Creek analysis showed a significant decrease in the occurrence of rapid rates-of-change of both the rising (Figure 10a; chi-square test for independence, $p=0.014$ ) and falling limbs (Figure 10b; chi-square test for independence, $p=0.019)$. Rates-ofchange that exceeded the highest threshold, nine times the median, occurred substantially less often downstream. Additionally, the rates-of-change were significantly different between sampling locations on the rising limb (Wilcoxon rank sum, $p=0.0006$ ) and on the falling limb (Wilcoxon rank sum, $\mathrm{p}=0.002$ ). 

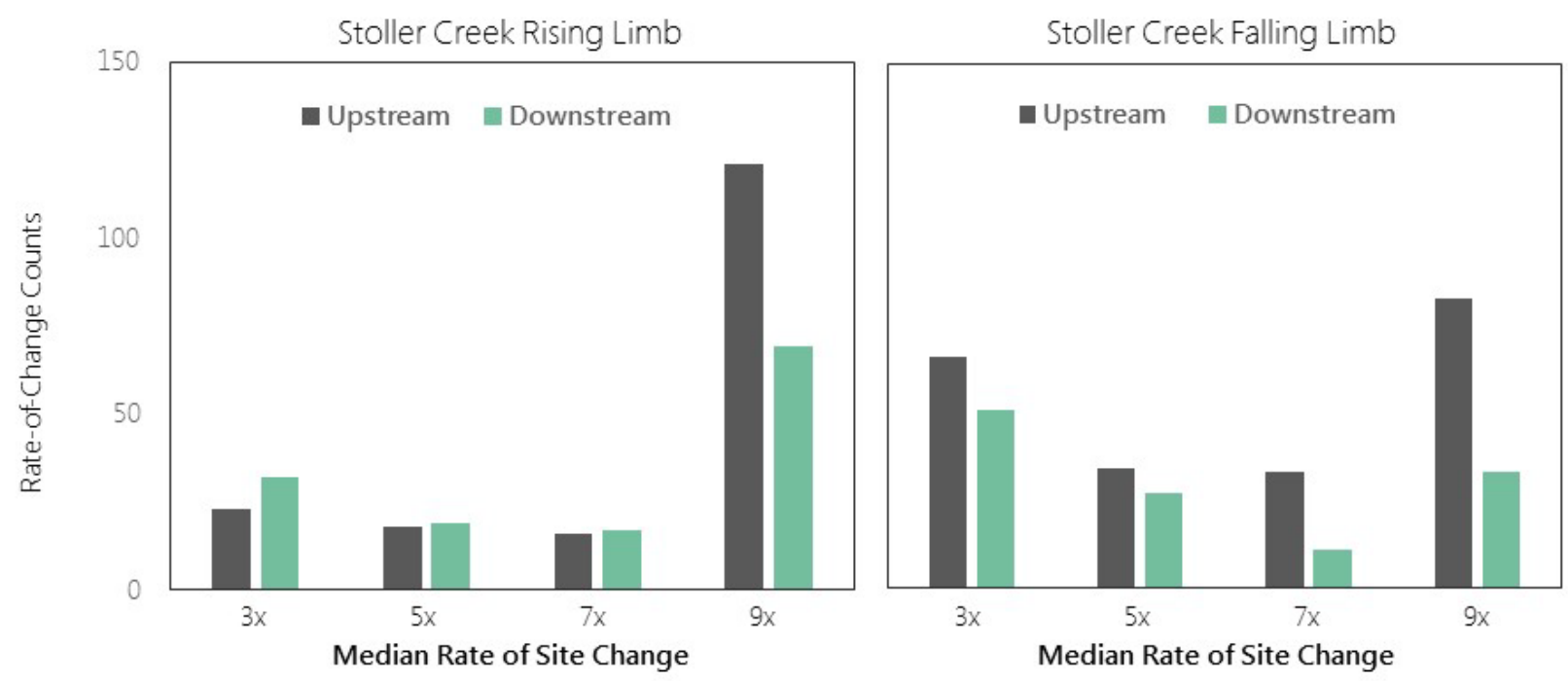

Figure 10. Findings from the frequency analysis of WCA rates-of-change at Stoller Creek show a slight, but consistent decrease in high rate-of-change events of the rising limb at the downstream site. The analysis of the falling limb shows a substantial decrease in the occurrence of high rate-of-change events downstream.

When comparing upstream Stoller Creek to upstream Fanno Creek, Fanno Creek was substantially flashier than Stoller Creek (Figure 11)-having greater WCA rates-of-change. On the rising limb, high rates-of-change occurred significantly more often at Fanno Creek than at Stoller (chi-square test for independence, $p=0.001$ ). Rates that exceeded nine-times the median occurred more than twice as much at Fanno than at Stoller. The same was true for the falling limb, where there were significantly fewer occurrences of high rate-of-change events at Stoller Creek (chi-square test for independence, $p<0.0001$ ). 

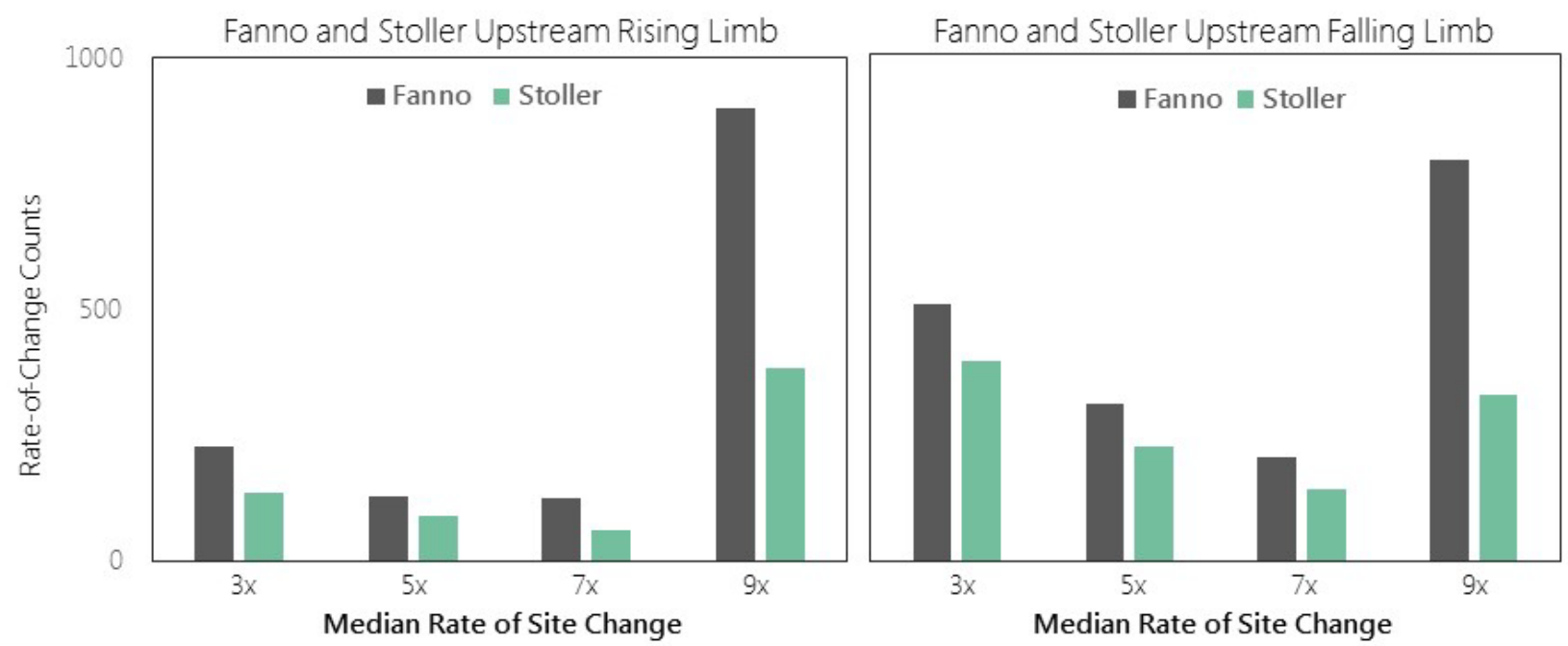

Figure 11. The frequency analysis of WCA rates-of-change comparing the upstream Stoller Creek site to the upstream Fanno Creek site, shows that Fanno has a flashier response to storm events than Stoller. The analysis was conducted on data collected from 2/18/2017 to 5/25/2017.

\subsection{Normalized Peak Magnitude Comparison}

Normalized peak magnitude (NPM) at Fanno Creek was often moderately lower at the downstream location. Attenuation appeared to increase as event size increased (Figure 12a). However, during periods of high flow, water exited the study reach laterally to an adjacent pond. A second comparison was made using only the storm events in which water remained in the study reach and did not overflow into the adjacent pond. Cross-sectional data from a bathymetric survey of the site (Figure 13) showed that multiple low-lying points occur along the margin of the channel (Figures 13, 14), where the maximum elevation is just 51.6 meters and water could escape the channel and not travel past the downstream sampling location. Events with a downstream peak that exceeded a water-surface elevation of 51.6 meters were 
removed for the second, modified analysis. Attenuation of the NPM did not increase as the event size increased for this analysis which the largest events were removed (Figure 12b). The NPM of storm events decreased downstream in 43 out the 49 events analyzed. A Wilcoxon signed-rank test showed that a significant $(p<0.001)$ difference in the NPM was present in the comparison between upstream and downstream sampling locations at Fanno.

(12a)

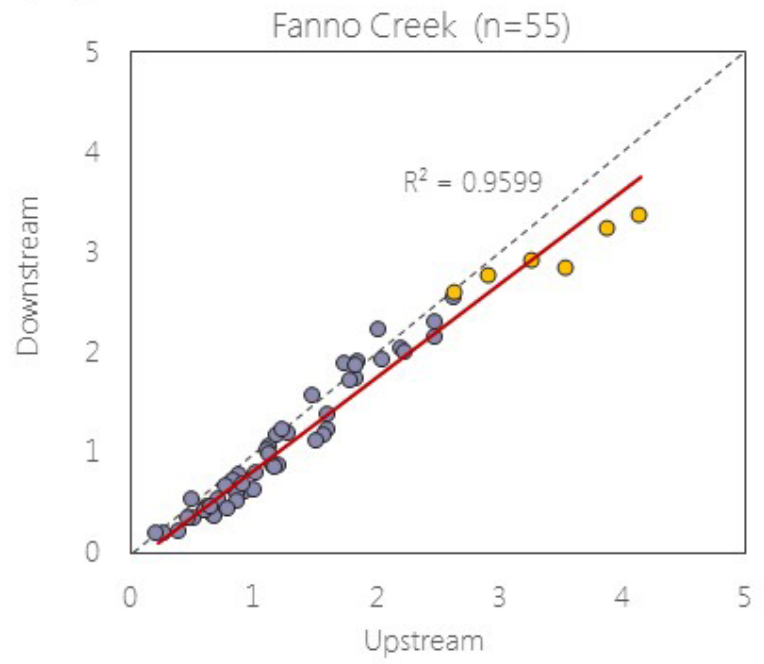

(12b)

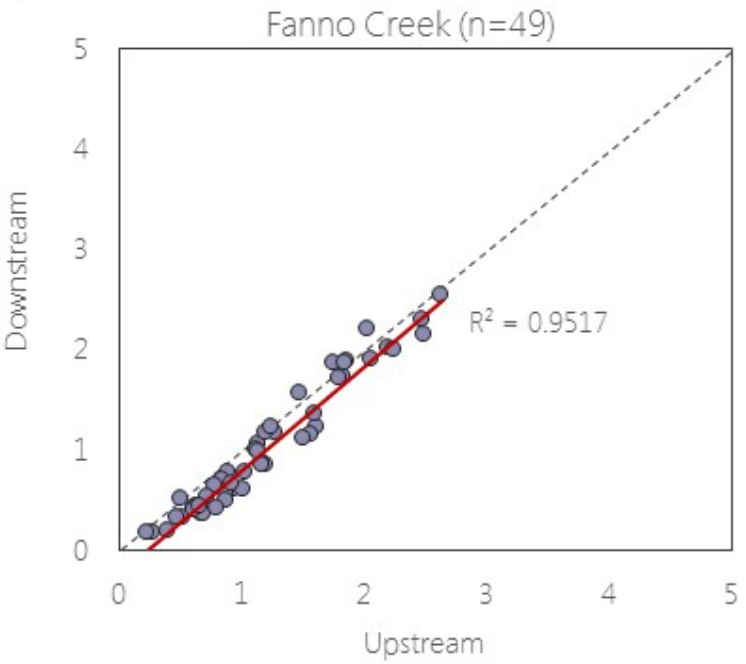

Figure 12. Normalized peak magnitude at the upstream site is plotted against the downstream site. The black dashed line represents a 1:1 relation. Plot 12a shows all 55 storm events. A decrease in the downstream magnitude of the larger storm events is apparent, highlighted in yellow. During a large storm event, water exits the channel and flows across the landscape, sometimes entering a neighboring pond. Such events were removed in the plot on the right to assess events where stormwater remained in the study reach. This plot (12b) shows that a modest decrease in normalized peak magnitude often occurs at the downstream site during these smaller events. 


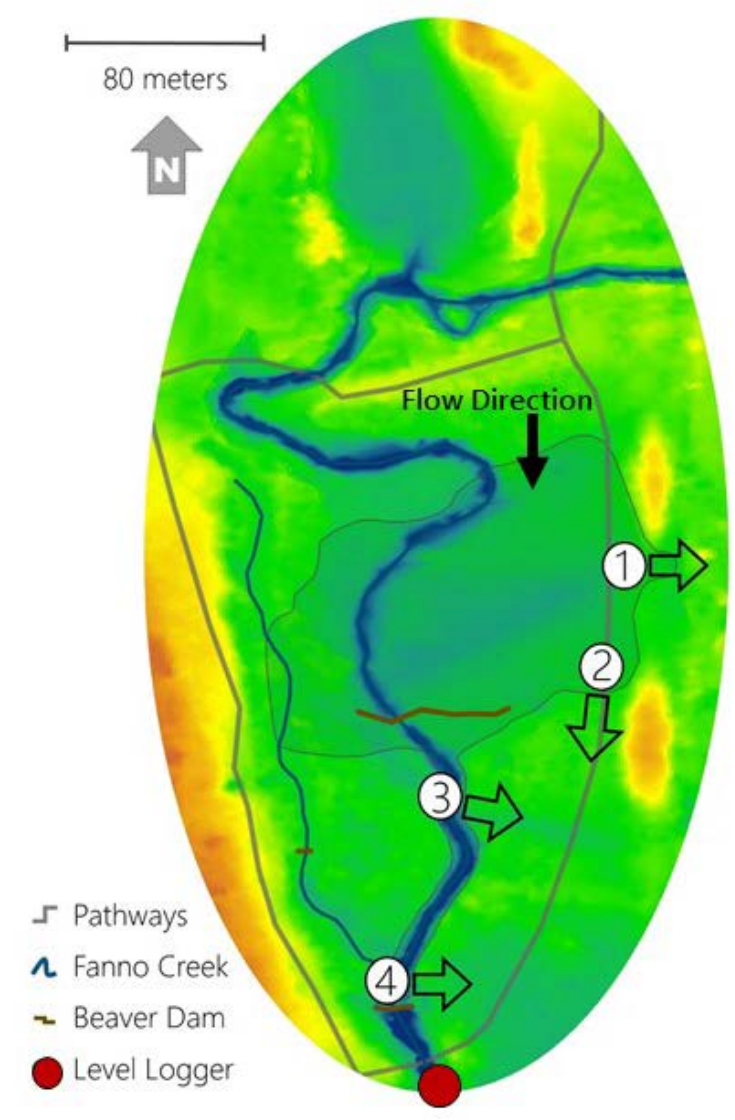

Figure 13. Map showing the bathymetric survey and the locations where water commonly exits the channel and the ponded area during large storm events. Point 3 shows the location of a beaver canal that developed over the study period.
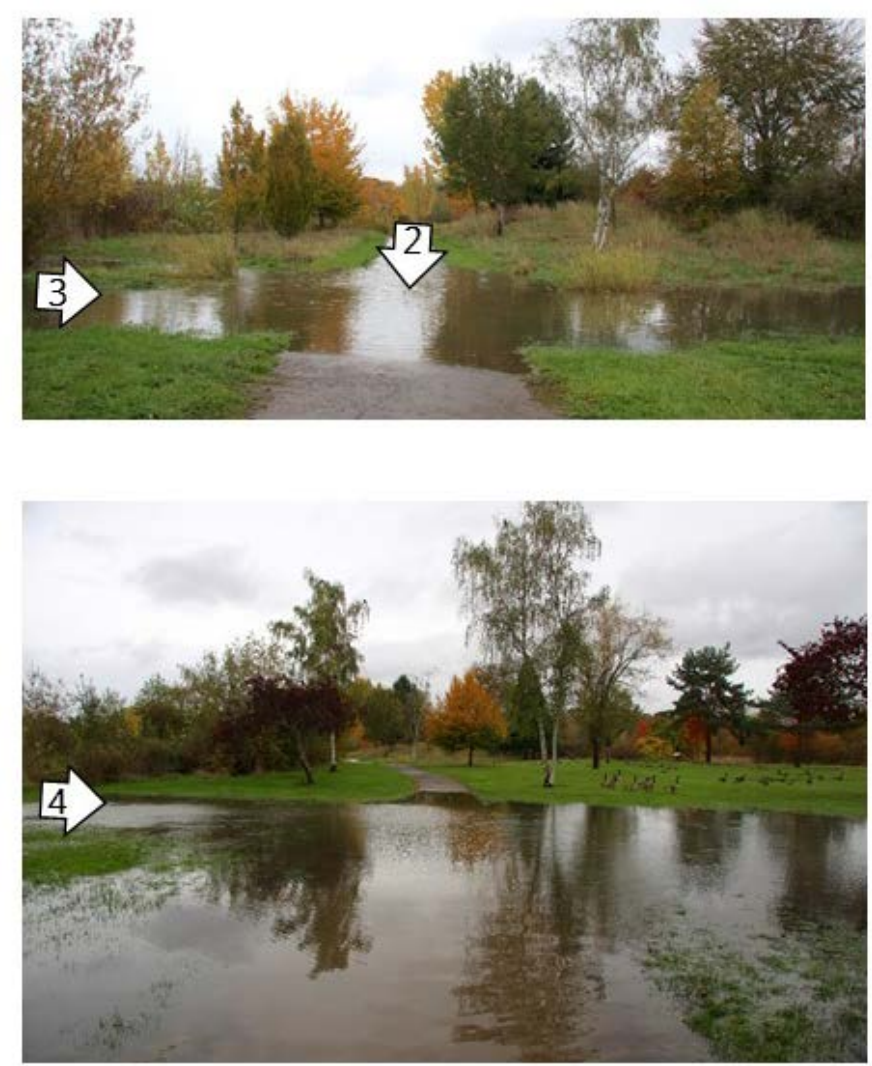

Figure 14. The two photographs above show a storm event on 10/22/17 where the water exited the channel and ponded area at approximately three points. The arrows show the direction of flow.

At Stoller Creek, a consistent decrease in NPM magnitude occurred at the downstream

location (Figure 15). This attenuation appeared to increase as the size of the event increased.

NPM decreased by an average of 54\% at the downstream Stoller Creek site for all 51 events.

A Wilcoxon signed-rank test showed a significant $(p<0.001)$ difference in NPM between the upstream and downstream sampling location. 


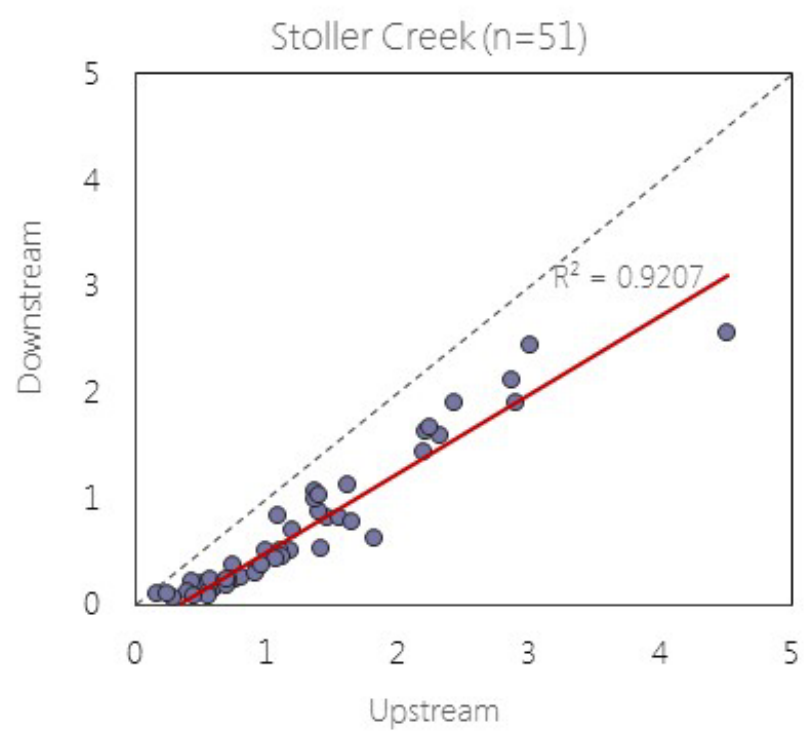

Figure 15. Normalized peak magnitude at the downstream Stoller Creek site is plotted against the upstream site. The black dashed line represents a 1:1 relation. Normalized pea magnitude is consistently smaller at the downstream site. As event size increases, attenuation appears to increase.

\section{DISCUSSION}

\subsection{Hydrologic Response During Storm Events}

Based on the results of this study, the presence of beaver dams and ponds in two urban streams in the Tualatin River Basin did have a modest effect on streamflow variability and storm event peak magnitude. The beaver dams forced water onto the floodplains at Fanno and Stoller Creeks, creating ponds that can store additional surface water on the landscape during storm events. A temporary storage and gradual release of water were detected at Stoller Creek. The ability of this reach to store water led to a slight decrease in the magnitude 
of storm peaks downstream of the beaver dams. The results suggest that the presence of beaver dams and ponds may have a larger effect on smaller streams, such as Stoller Creek.

The results from the WCA rate-of-change frequency analysis showed a significant difference in the response of the storm hydrograph's rising limb between the upstream and downstream sampling locations at both Fanno Creek and Stoller Creek. This suggests that the beaver dams and ponds are buffering the intensity of the storm events. Interestingly, the response on the falling limb at Fanno Creek was similar between the upstream and downstream locations, but there was a significant difference in the falling limb between the sampling locations at Stoller. The reason for the disparity between the results was unclear. One possible explanation may relate to the contrast between the sites' contributing areas (Figure 16). The two study reaches are similar in length, but Fanno Creek has a more extensive stream network contributing to flow at the study site. According to the U.S. Geological Survey StreamStats program (USGS, 2018), the expected discharge during a 2year peak flood is $278 \mathrm{ft}^{3} / \mathrm{s}$ at the upstream Fanno Creek site and $13 \mathrm{ft} / \mathrm{s}$ at the upstream Stoller Creek site (Table 1). Additionally, a larger portion of Fanno Creek's contributing area is classified as impervious (4 mi², 42\%), compared to Stoller Creek (0.1 mi², 18\%). More impervious surface area likely created a greater volume of runoff that was routed quickly to the stream network during storms, which increased stream flashiness. Results from the frequency analysis comparing Stoller Creek to Fanno Creek confirmed that Fanno Creek is

\section{Page | 29}


significantly flashier than Stoller Creek. The additional water added to the system may influence how effective the network of beaver dams was at attenuating flow.
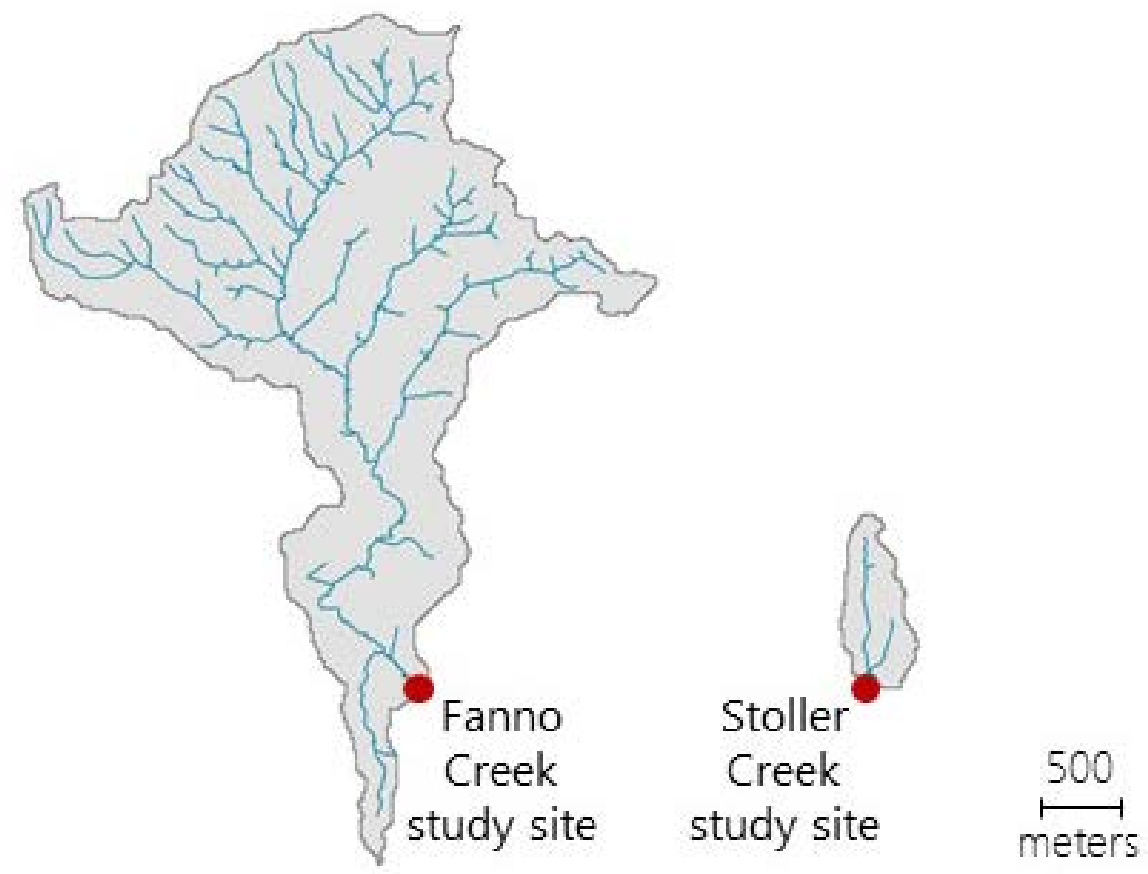

Figure 16. The upstream Fanno Creek study site has a contributing area of $26.7 \mathrm{~km}^{2}\left(10.3 \mathrm{mi}^{2}\right)$, whereas $1.4 \mathrm{~km}^{2}\left(0.53 \mathrm{mi}^{2}\right)$ feeds the upstream Stoller site.

Other potential explanations for the differences in rising limb behavior between the study sites include differences in floodplain accessibility and storage, as well as in the availability of dam building materials. It is possible that the storage capacity of the beaver reach at Fanno Creek was near its limit and therefore could not store enough water to have a greater attenuation effect during storm events. There were areas within the wide, unconfined floodplain at Fanno Creek that were not accessed by the stream during storm events. However, the height of the dams and their locations on the landscape did not create 
conditions that allowed these areas to be reached during high flows; instead, water would flow over and around the dams. At Stoller Creek the floodplain is narrower and confined by the topography. There were areas within the floodplain that were not observed to be inundated during periods of low flow, but these areas were often accessed by the stream during storm events. Additionally, dams in the two study reaches were built of noticeably different materials. Dams at the Fanno Creek study reach were made primarily of sticks with some packed mud, allowing water to partially flow through them year-round. The dams at Stoller Creek were made with sticks and heavily packed with mud. The mud likely assisted in preventing water from leaking through the dam, which could result in longer term storage or more effective displacement of water to the floodplain.

\subsection{Limitations to Study Design}

This study examined only two stream reaches, which represent a small portion of the stream network in the TRB and a small sample of various dam characteristics, stream slopes, and floodplain sizes, to name just a few potential differences among streams. Future studies would benefit from including a wider range of stream sizes and dam types to better understand the degree of stormwater attenuation that might occur in a variety of streamscapes. This work could also uncover the landscape factors that best support

stormwater attenuation in beaver-affected reaches, and help resource managers understand where best to encourage beaver activity to reap a maximum level of benefit. 
The results presented in this paper represent the effects beaver dams have on stream flashiness over a brief period of time. These effects are not stable or permanent because beaver continually alter the environment to fit their needs. Beaver will extend the dimensions of their dams and build additional dams as needed. Additionally, they are a transient species that may abandon a location once their food resources have become depleted. It is not reasonable to expect a consistent stormwater attenuation effect once a network of beaver dams is established. Even if landscape factors remain the same, beaver dams will likely change in length and height, and increase in number over time as beaver alter the stream to fit their needs. Beaver ponds can also trap large quantities of sediment and aggrade incised streams, resulting in an increase in floodplain connectivity that might help to attenuate stormwater, or change the degree of attenuation at different flows. Eventually dams will be abandoned and no longer maintained. It is possible that stormflow attenuation could be reduced or completely diminished once a beaver dam is no longer maintained. It would be beneficial to examine if and how the stormwater attenuation effect of a beaver affected reach changes over time as the network of dams evolves and eventually becomes abandoned. 


\subsection{Effects of Dam Notching}

During the data-collection period at Greenway Park, the Tualatin Hills Parks and Recreation District staff notched the most upstream dam to reduce water levels and prevent flooding on the main nearby trail (Figure 4). A decrease in surface-water elevation was measured 0.33 river miles upstream and a brief increase in water-surface elevation was measured downstream (Figure 17). Based on these measurements, this upstream and smallest dam appeared to cause a measurable backwater effect that extended beyond the perceived ponded area, farther upstream than originally anticipated. The beaver dams apparently can impede flow in the channel even when a backwater condition is not obvious.
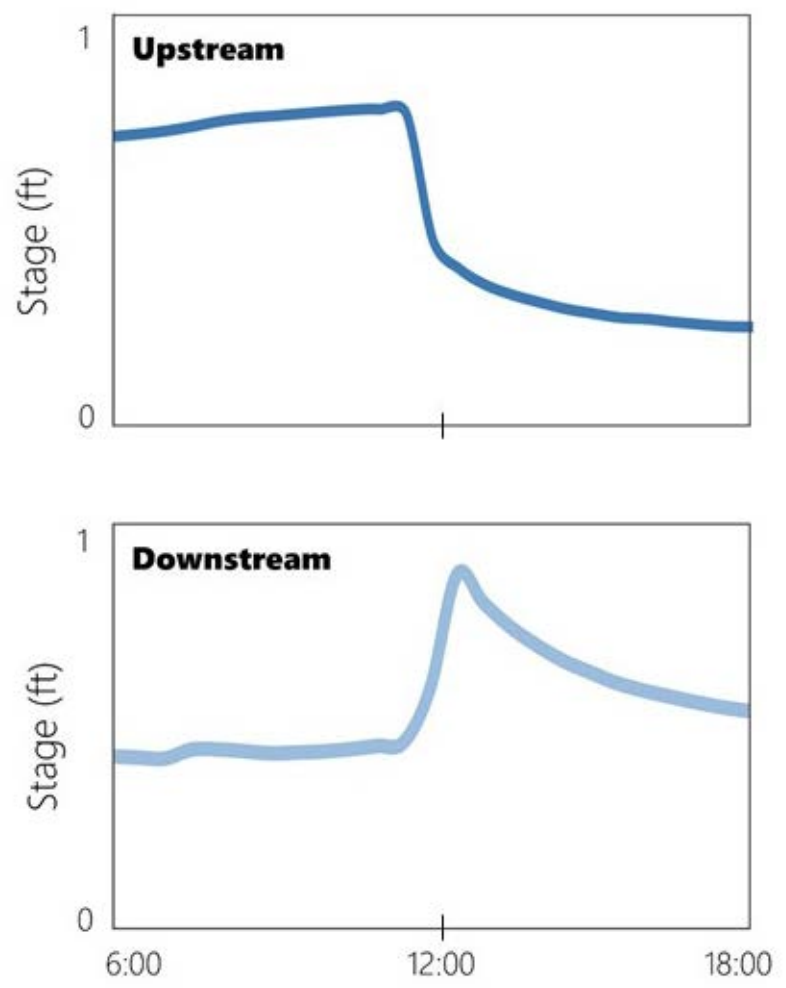

Figure 17. Example of a dam notching event that occurred on June 18, 2016 around 11:30 a.m. Stage dropped 0.33 river miles upstream of the notching and a brief rise in stage was observed downstream. 


\subsection{Implications for Management}

If beaver dams are to be used as a means of limiting or mitigating hydromodification in the TRB, it is imperative that resource managers understand the conflicts that may arise due to beaver dams and ponds, and where these conflicts are most likely to occur. In an urban setting, flooding may be a greater concern than in rural areas, because urban areas tend to have large amounts of infrastructure or development in or near floodplains that would be vulnerable to a rise in water level. Beaver activity can plug culverts and increase localized flooding risks to roads, buildings and homes located close to the stream network. A conflict model would locate areas of highest and lowest concern, allowing resource managers to be proactive when managing areas where beaver activity is not favorable. In areas of low concern, beaver activity could be encouraged through restoration activity, such as vegetation planting. In areas where conflicts of high concern are most likely to occur, resource managers could actively discourage beaver activity by fencing trees and planting species that beaver do not utilize for dam building or foraging. In some situations, it might be appropriate to provide structural support to a beaver dam. Dams in incised channels are more likely to breach during storm events because velocity is often higher due to the disconnection between the stream and its floodplain (Pollock, et. al., 2012). Structural support also might be beneficial in areas where a dam breach could cause downstream flooding that would affect infrastructure.

\section{Page | 34}


Organizations and agencies that may come across conflicts with beaver (such as city staff, department of transportation, parks department, etc.) would benefit from information on how to coexist with beaver. A framework that explicitly lays out potential conflicts and management options (such as the decision tree proposed in Figure 18), could lead to more consistent management actions across the basin. A framework would also cut down on the response time between the occurrence of potentially negative beaver activity and the response from agencies. Beaver work quickly, so it is important for agencies to act just as quickly in situations where beaver activity might cause a problem.

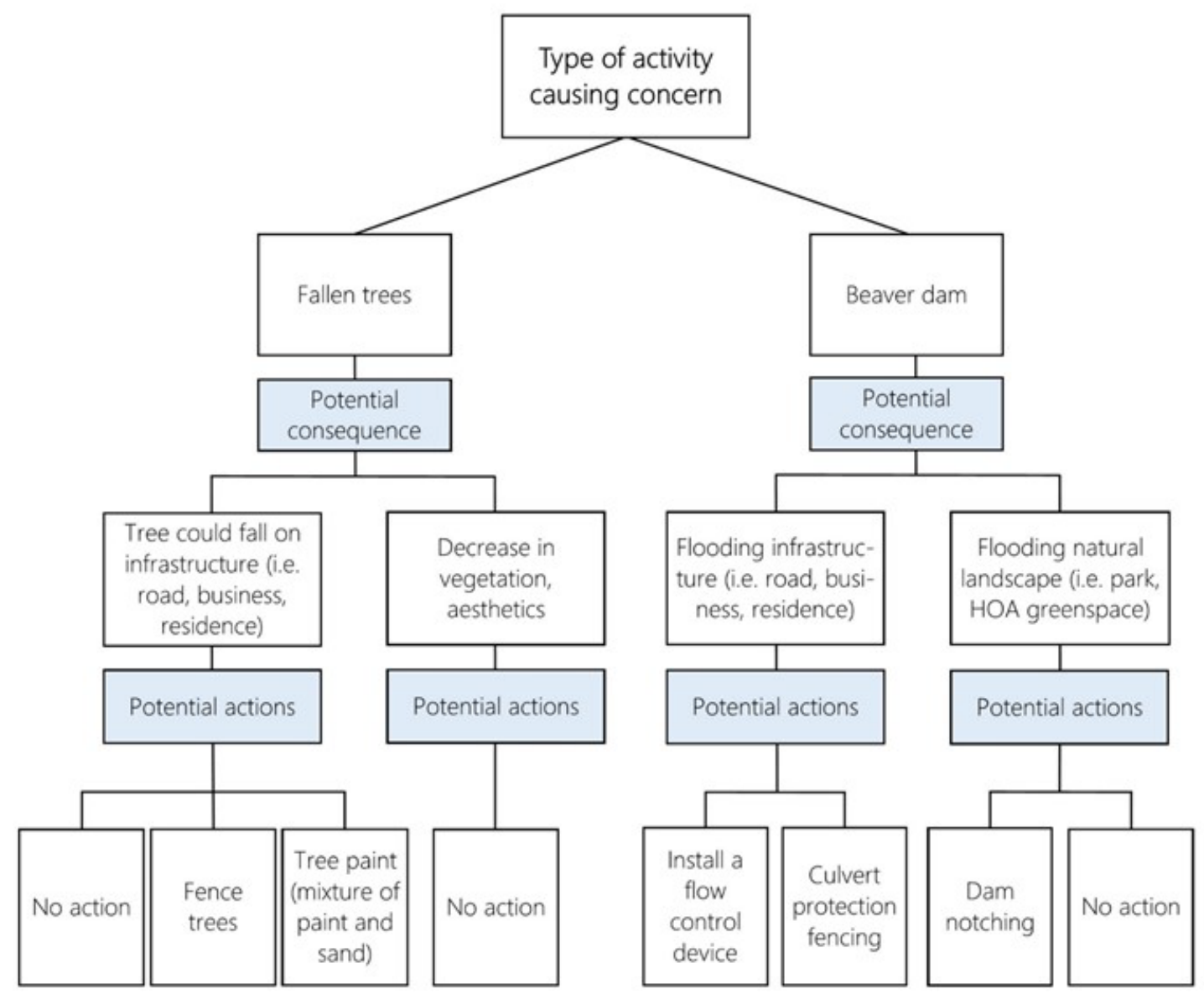

Figure 18. Example of a decision tree to help resource managers decide what action to take. 


\section{CONCLUSION}

Results from this study of two beaver-affected reaches demonstrate that beaver dams and ponds can potentially be used as a tool to minimize the effects of hydromodification. Modest stormflow attenuation was observed at the study sites with beaver activity, but beaver dams and ponds alone cannot remediate the flashy response that typically occurs in urban streams, such as Fanno and Stoller Creeks. The volume and timing of runoff entering streams continues to be a concern for resource managers of urban streams. Additionally, the degree of stormwater attenuation appears to be site specific. More research on the hydraulic response of beaver-affected reaches across a variety of sites and over a longer timeframe would help resource managers understand where to promote beaver activity in order to obtain the most benefit. 


\section{REFERENCES}

Arnold, C. L., Gibbons, C. J., 1996, Impervious surface coverage-The emergence of a key environmental indicator, Journal of the American Planning Association 62:243-258, DOl: 10.1080/01944369608975688

Baker, D. B., Richards, R. P., Loftus, Timothy., Kramer, Jack., 2004, A new flashiness index: characteristics and applications to midwestern rivers and streams. Journal of American Water Resources. Paper No. 03095

Bonn, B., 2016. 2016 Tualatin River Flow Management Report. Tualatin River Flow Management Technical Committee.

Booth, D., 1990, Stream-Channel Incision Following Drainage-Basin Urbanization, Water Resources Bulletin, Paper No. 89098, doi.org/10.1111/j.1752-1688.1990.tb01380.x

Booth, D., Konrad, C., 2017, Hydrologic metrics for status-and-trends monitoring in urban and urbanizing watersheds, Hydrological Processes. 2017;31:4507-4519.DOI:

10.1002/hyp.11369

Brown, L., Cuffney, T., Coles, J., Fitzpatrick, F., McMahon, G., Steuer, J., Bell, A., May, J., 2009, Urban streams across the USA: lessons learned from studies in 9 metropolitan areas, Journal of the North American Benthological Society, 28(4):1051-1069, doi.org/10.1899/08-153.1

Chang, H., 2007, Comparative streamflow characteristics in urbanizing basins in the Portland Metropolitan Area, Oregon, USA, Hydrologic Processes, 21, 211-222 (2007), DOl:

10.1002/hyp.6233 
Giriat, D., Gorczyca, E., Sobucki, M., 2015, Beaver ponds' impact on fluvial processes, Science of the Total Environment, 544 (2016) 339-353, doi:10.1016/j.scitotenv.2015.11.103

McMahon, G., Bales, J., Coles, J., Giddings, E., Zappia, H., 2003, Use of Stage Data to Characterize Hydrologic Conditions in an Urbanizing Environment, Journal of the American Water Resources Association, Paper No. 03058

Microsoft Office, version 2016, Microsoft Excel

Nyssen, J., Pontzeele, J., Billi, P., 2011. Effect of beaver dams on the hydrology of small mountain streams: Example from the Chevral in the Ourthe Orientale basin, Ardennes, Belgium. Journal of Hydrology 402 (2011) 92-102, doi:10.1016/j.jhydrol.2011.03.008

Ozawa, C., Yeakly, A., 2007. Performance of Management Strategies in the Protection of Riparian Vegetation in Three Oregon Cities. Journal of Environmental Planning and Management, Vol. 50, No. 6, $803-822$

Phillips, C.B., Scatena, F.N., 2010, Flashiness Indices for Urban and Rural Streams in Puerto Rico, AWRA 2010 Summer Specialty Conference

Poff, L., Allan, D., Bain, M., Karr, J., Prestegaard, K., Richter, B., Sparks, R., Stromberg, J., 1997, The natural flow regime: A paradigm for river conservation and restoration, American Institute of Biological Sciences, Oxford University.

Pollock, M. M., J. M. Wheaton, N. Bouwes, C. Volk, N. Weber, and C. E. Jordan. 2012. Working with beaver to restore salmon habitat in the Bridge Creek intensively monitored watershed: Design rationale and hypotheses. NOAA Technical Memorandum NMFS- NWFSC-120:1-47 
Puttock, A., Graham, H., Cunliffe, A., Elliott, M., Brazier, R., 2016, Eurasian beaver activity increases water storage, attenuates flow and mitigates diffuse pollution from intensivelymanaged grasslands, Science of the Total Environment. doi.org/10.1016/j.scitotenv.2016.10.122

R Core Team, 2013. R - A language and environment for statistical computing. R Foundation for Statistical Computing, Vienna, Austria, http://www.R-project.org/

Richards, K.D., Scudder, B.C., Fitzpatrick, F.A., Steuer, J.J., Bell, A.H., Peppler, M.C., Stewart, J.S., Harris, M.A., 2010, Effects of urbanization on stream ecosystems along an agriculture-tourban land-use gradient, Milwaukee to Green Bay, Wisconsin, 2003-2004: U.S. Geological Survey Scientific Investigations Report 2006-5101-E, 210 p.

Rynerson, C., 2017, PSU Report: New residents continue to drive Oregon's population growth, PSU Population Research Center, Portland, Oregon

Smith, K., Ory, J., 2005, Healthy Streams Plan, Clean Water Services, Hillsboro, Oregon, www.cleanwaterservices.org/media/1298/healthy-streams-plan.pdf

U.S. Geological Survey, 2018, The StreamStats program, online at http://streamstats.usgs.gov.

Westbrook, C., Cooper, D., Baker, B., 2006, Beaver dams and overbank floods influence groundwater-surface water interactions of a Rocky Mountain riparian area, Water Resources Research, VOL. 42, W06404, doi:10.1029/2005WR004560

Wright, J., Jones, C., Flecker, A., 2002, An ecosystem engineer, the beaver, increase species richness at the landscape scale, Ecosystem Ecology, Oecologia (2002) 132:96-101, DOI 10.1007/s00442-002-0929-1 
Appendix A - Community Partner

\section{The U.S. Geological Survey (USGS) Oregon Water Science Center}

The USGS Oregon Water Science Center works with partners to provide high quality, impartial data to better understand water resource issues and support management and planning decisions. Clean Water Services (CWS), a local wastewater and stormwater management agency, has been partnering with the USGS since the early 1990s to better understand challenges facing the Tualatin River and its tributaries and use science as the foundation for decision-making. The USGS/CWS Tualatin study is one of the longest running continuous studies at the USGS Oregon Water Science Center, resulting in a great wealth of knowledge about how Tualatin River Basin streams function, which has led to improvements in stream health.

\section{The Urban Beaver Study}

Currently, the USGS and CWS are studying the effects of beaver dams and ponds on urban streams in the Tualatin River Basin, Oregon. The goal is to quantify changes to water quality and quantity to answer the following overarching questions: (1) can beaver dams and ponds help to mitigate some of the hydromodifications associated with urban development, and (2) can beaver be used as a tool to help manage stormwater and restore water quality? 
The impetus for this study came when Clean Water Services was asked by the Department of Environmental Quality to incorporate a hydromodification management plan into their watershed permit. As CWS staff considered potential in-stream and out-of-stream tools to include in their plan, they wondered if beaver, an animal native to the area and increasing in abundance, could be used as such a tool. The current literature states that beaver ponds and dams act to attenuate streamflow during storms and provide ecological uplift in rural areas that have less anthropogenic change. But urban stream systems present unique challenges that are not common in rural systems. The lack of research and need for more site-specific data prompted this study.

\section{My Role in the Urban Beaver Study}

I began working for the USGS in the summer of 2016 as a hydrologic field assistant. In the fall of 2016 I advanced to the position of a student intern (hydrologist). The internship program, referred to as the Pathways Program, was developed to provide employment opportunities to students as they work towards their degree. My position will allow me to convert to term employment once I have completed my Masters program. Since I started with the USGS, my primary role has been to work on various aspects of the urban beaver study. 
During the one-and-a-half-year data collection period I accomplished the following:

o Collection and data management of continuous temperature measurements at 28 sites with the goal of understanding spatial and temporal diversity in stream temperature in beaver-affected reaches.

o Assisted in organizing and conducting three temperature synoptics to measure spatial variability in surface water temperature on hot days.

o Collection and data management of continuous surface water elevation data at nine locations and groundwater elevation data at eight locations.

o Assisted in the maintenance and calibration of six water quality sondes.

o Assisted in the collection of bathymetric data and other elevation data using both a total station and a real time kinematic surveying tools.

o Assisted in organizing and conducting suspended-sediment samples during numerous storm events.

Data collection ended in the fall of 2017, and since then my role in the study has changed. I am currently working to process and analyze the temperature and surface-water elevation data. Once data analysis has been completed, I will be writing about the results of the study and continuing to present the findings. 
In an effort to educate the public about this study, and to improve my communication skills, I have completed a number of talks and provided site tours to various groups. These accomplishments include (but are not limited to) the following:

o State of the Beaver Conference, February 2017

o American Fisheries Society, Oregon Chapter, Annual Conference, March 2018

o Brown Bag Presentation for the Environmental Water Resources Group, a subgroup of the American Society of Civil Engineers, January 2018

o Urban Ecology and Conservation Symposium, February 2018

o Tualatin River Watershed Council, April 2018

o Site tour for folks from CWS and ODEQ, September 2017

o Site tour for students from Portland State University ESM Department, October 2016

My time at the USGS has been extremely valuable to me. I have learned more during this time than I would have thought possible and I have grown as a person and employee because of it. I've met and befriended many amazing scientists that constantly impress me with their kindness, intelligence and curiosity of the world around them. 